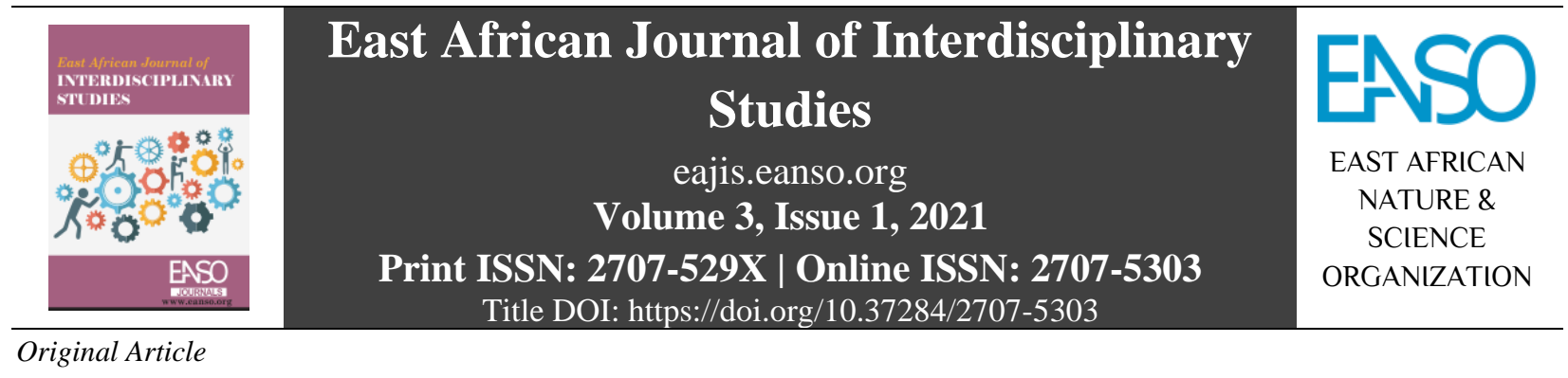

\title{
Role of Statues in the Artistic Commemoration of African Political Leaders: Analysis of 20 Selected National Statues in African Countries.
}

\author{
Dr. Kamau Wango, $P h D^{1 *}$
}

${ }^{1}$ Department of Fine Art and Design, Kenyatta University, P. O. Box 43844 - 00100, Nairobi, Kenya.

* ORCID: https://orcid.org/0000-0002-0185-1355. Author for Correspondence email: kamauwango@ gmail.com.

Article DOI: https://doi.org/10.37284/eajis.3.1.295

\section{Date Published: ABSTRACT}

12 March 2021 Artistic commemoration of leaders and other iconic personalities has been in existence for centuries. Statues in particular have been used as a

Keywords: fitting avenue for the commemoration of political leaders and other luminaries in many fields. The premise upon which statues are made is

Statues, that the subjects featured initiated and attained, in their lifetimes, Physical Likeness, concrete achievements that significantly impacted upon the lives of their

Posture, fellow human beings. Other criteria for commemoration include proven

Commemoration, integrity, dedication and selflessness in the service of the country and

Legacy, citizens. Statues as an integral part of public art have often generated

Public Spaces. substantial controversy on various fronts in many countries. Some of these gravitate around issues such as disputed likeness, queries about the fundamental achievements cited of the subject, at times open protests on the actions, character and integrity of the subject as well as the location of the statues. Other areas of contention include the implication of the presence of statues upon the political psyche of the country and their long-time impact on history, the youth and posterity. This paper examines the extent to which African countries have embraced this mode of artistic rendition to commemorate African political leaders in a way that is commensurate to their achievements. It is outside the scope of this paper to delve into the intricate web of back-and-forth arguments about the 'concreteness' of the legacies of the featured leaders who are mainly founding political figures of the respective countries. The paper, however, analyses the artistic essence of the selected statues in terms of their visual impact and whether they are indeed useful in articulating the legacies of the subjects and further, whether they ultimately bear 'enduring visual value' that spurs conversation and insight into these legacies. Statues must, at the very least, spur debate and conversation into the legacy of the featured subject. It becomes a form of constant 
interrogation as history itself takes its course; controversy is not necessarily a negative occurrence since it forms part of this discourse. The concept of immortalization, which is what initiators of statues often hope for is much harder to achieve and difficult to define. The paper examines 20 statues of African political leaders in different African Countries.

\section{APA CITATION}

Wango, K. (2021). Role of Statues in the Artistic Commemoration of African Political Leaders: Analysis of 20 Selected National Statues in African Countries. East African Journal of Interdisciplinary Studies, 3(1), 40-77. https://doi.org/10.37284/eajis.3.1.295

\section{CHICAGO CITATION}

Wango, Kamau. 2021. "Role of Statues in the Artistic Commemoration of African Political Leaders: Analysis of 20 Selected National Statues in African Countries.”. East African Journal of Interdisciplinary Studies 3 (1), $40-77$. https://doi.org/10.37284/eajis.3.1.295.

\section{HARVARD CITATION}

Wango, K. (2021) "Role of Statues in the Artistic Commemoration of African Political Leaders: Analysis of 20 Selected National Statues in African Countries.", East African Journal of Interdisciplinary Studies, 3(1), pp. 40-77. doi: 10.37284/eajis.3.1.295.

\section{IEEE CITATION}

K. Wango, "Role of Statues in the Artistic Commemoration of African Political Leaders: Analysis of 20 Selected National Statues in African Countries.”, EAJIS, vol. 3, no. 1, pp. 40-77, Mar. 2021.

\section{MLA CITATION}

Wango, Kamau. "Role of Statues in the Artistic Commemoration of African Political Leaders: Analysis of 20 Selected National Statues in African Countries.”. East African Journal of Interdisciplinary Studies, Vol. 3, no. 1, Mar. 2021, pp. 40-77, doi:10.37284/eajis.3.1.295.

\section{INTRODUCTION}

In examining the role of statues in the commemoration of African political leaders, this paper does not dwell on the merits or demerits of the leadership of the featured leaders and does not refer to any performance indicators. After all the leaders' statues are already erected indicating that commemoration has already been initiated. The paper, instead, confines itself to short glimpses of what made these leaders stand out at the outset. Most were founding fathers of their respective countries, founding leaders of pioneering political parties or founders and leaders of their armies, or played a pivotal role in their respective country's independence. However, there is no leader who is completely free of fault or some blemish that can be attributed to them individually or to their regime. It is, therefore, generally acknowledged that these leaders, love them or hate them, were of significant political value to their people. In this regard alone, they deserve to be commemorated because those events, particularly in regard to the clamour for independence, were uniquely significant and are not replicable or erasable. This paper is, however, more inclined towards examining the role of statues as public art in commemoration, than interrogating the legacies of the leaders themselves.

Although some critics have advocated for the historical dismissal of some of these leaders, it cannot be denied, though, that they played a pivotal role in the events that led to their respective countries' independence, be they liberation wars, complex negotiations, intrigues and initiatives that laid the foundation for their new Nations. Many of them also took significant steps that enabled their countries to take off in terms of social/economic development in the immediate post- 
independence years. This paper takes cognizance of the fact that the picture was not, however, all rosy; that in the process, controversies, queries of national trajectories, accusations of betrayal, disappointments and even outright public anger permeated through the general populace. This was evident in the way the leaders governed, the ideological paths they took, the policies they implemented and the general resonance they built or failed to build with their people. Some of them made fundamental social/political and economic mistakes and their politics and policies, in many instances, failed their people and caused great suffering and bitterness leading to political and emotional sensitivities. Some, indeed, were overthrown in military coups and some died in office while others were defeated in popular multi-party elections. In terms of history, however, some of them have been dead long enough for history to have its say, the question has always been what then to do with their legacies; can they or should they be discarded and confined to the periphery of history or even the dustbins of history? The answer is certainly debatable and emotive and needs careful consideration; most of them meant well and worked hard in the formative years but perhaps deviated somewhere along the way. Some achieved great strides and some even left power voluntarily.

It is important to include this short discourse because artistic commemoration itself and specifically that which is expressed through statues, is not done in a vacuum; it must be seen to be done in the background of solid justification for it to be sensible and appreciable. The role of the statues themselves is to underscore the concept of commemoration and thereby seek to commit the legacy of these leaders into the annals of memory. The omnipresent physicality of statues and their likeness to the subject are ideally designed to both captures and rekindle the spirit of the leaders at the height of their fame, at the glory of their best actions; at the moment of their best judgment and in the light of their best character. It has been observed, of course, that statues have at times attracted the opposite reaction. The social/political role of the statues as well as their role in popular culture is to elicit inspiration through memory and remembrance. The verdict of history, however, must be factored in as an important stamp of approval. A main drawback of statues manifests itself if there remains a significant query on the legacy of the subject of commemoration that draws emotive reactions among the audience that pushes the statue towards the edge-line of acceptability.

\section{Description of Artistic Commemoration}

Commemoration sifts the unique from the ordinary and commits to the memory events, occurrences and historical figures. Thus, when commemoration occurs, meaning is assigned to an event, an occurrence or to individuals or groups of people who are all deemed to have impacted society in a unique, transformative and enduring manner. Artistic commemoration occurs, therefore, when an artistic component is added to the concept of commemoration in order to visually aid the respective objective of commemoration through a selected type of art. Hence there must be an 'objective' of commemoration and subsequently a 'subject' of commemoration upon which art is applied. Frank and Preble (2011) define commemoration as 'something done as an aid to memory and artwork made for this purpose links us with humanity that stretches back in time. Commemoration makes our lives seem more significant and valuable.' This is important because the purpose of commemoration, particularly when viewing a statue is to find significance in the subject's achievements as a way of reflecting upon the psyche of the audience. The audience then strives to achieve what they can at their own level and in their own definition; in other words, they find a convergence point of emulation. Frank and Preble further observe 
that, 'thought of by many as a personal opportunity to hold memories of people important in our lives, the commemoration is often more of a public celebration or honouring of an individual, their actions or an event.'

Artistic commemoration has manifested itself over the ages through many ways including ancient cave paintings commemorating hunting expeditions, paintings that depict events and occurrences, portraits that depict individuals, stamps, currency, coins, architectural monuments, sculptural busts and statues themselves. Statues include those of individuals as well as groups signifying a specific event, occurrence or message.

The execution of artistic commemoration entails holistic work functions as both a focus of commemoration and also as an aesthetical public work of art that is able to draw the attention and successfully engages the transient audience. Moran (2007) notes that "Commemorative public art is intended to ensure that the public remembers a key event or person through the representation of an aspect of that person or event in the form of a public artwork." Artistic public commemoration presupposes that there exists a link or relationship between the 'power of art' and the 'power of memory'. In regard to artistic avenues of commemoration and statues, in particular, the concept of the power of art remains constant; that is, statues, for instance, possess in many circumstances, a strong visual presence able to attract the attention of audiences and passers-by. However, the power of memory can be problematic. Memory has been described as a psychological response to external and internal stimuli through which recollections from the past are induced and events reconstructed. When a statue is not very old, those audiences who may have encountered the subject of commemoration in their lifetimes and are familiar with his or her actions, weaknesses, character, accomplishme nts or failures may be in a position to recollect these factors out of actual memory. In such cases, the link between the power of art and the power of memory is defined and consolidated. Those audiences, including posterity, who obviously did not and shall not encounter the subject of commemoration may have a challenge with recollection since they lack a tangible memory footprint in their minds and, hence, have no reference point in their memory.

In commemoration, this gap is filled by historical information and constant reminder of the essence of the contribution of the subjects, through structured and purposeful documentation and dissemination of information, performances and ceremonies. When this is not constant, structured, purposeful or even present through education and other modern channels of communication, particularly aimed at the youth, then the concept of commemoration itself loses its meaning, despite the power of Art. In view of this, this paper postulates that artistic commemoration must be anchored on a spirited and omnipresent mode of dissemination of educative materials and information, particularly in the age of advanced electronic technology, on the essence and relevance of the contribution of selected subjects of commemoration who occupy in death, as they did in life, a unique spot in the history of their countries and their peoples. It is presumed, of course, that this information would include a careful, balanced and fair assessment of their legacies.

\section{APPLICATION OF ARTISTIC COMMEMORATION THROUGH STATUES}

As observed in the definition of commemoration, any aspect of commemoration is always accompanied by a specific objective upon which an artistic concept is applied to actualize the commemoration itself. In the commemoration of the lives and legacies of many African leaders, it has become evident that statues have become a significant artistic 
platform through which commemoration is achieved. This is mainly because, though expensive, a statue is seen and recognized as public art that directly engages the public. It is also a way in which physical likeness can perhaps be best rendered because of its threedimensional nature. Unlike a painted portrait, it has 'quasi-real' physical presence because it is presented fully in the round and if the likeness of face and body posture is accurate, it can have profound visual appeal.

The main feature of any statue is its representational strength. Accurate depiction of physical likeness in turn helps to construct a perception of character and personality; it is only a perception because, just like in painted portraiture, these attributes are not visually determinable, they can only be 'inferred'. Statues, therefore, that have not been successful in commemorative terms have almost certainly had a problem with the acceptability of likeness. Likeness is, hence, the only link between the subject of representation and the audience; when the likeness is absent, then there is no longer any channel of interaction between the subject and the transient audience, no matter how else the artistic aspect or other embellishments have been accomplished. The artist not only has to get the facial and body characteristics correct; the enlargement also has to be proportionately correct.

Another major aspect of statues in commemoration is the use of gestures. Statues have a certain static gestural presentation that is designed to communicate the desired message. This gestural presentation is usually aligned to a popular characterization of the subject of commemoration that helps to enhance the memory of that individual's personality. Gestures, though static, are also designed to 'rally' the audience to the spirit of the subject's cause that is itself aligned to the Country's perpetual or 'eternal' aspirations. For example, Nkrumah's (Plate 2a) agile forward march and outstretched pointing hand symbolizes Ghana's 'forward ever' futuristic notion; Mandela's raised fist salute (Plate $4 b$ ) is not only a symbol of his own personal freedom but first and foremost a symbol of the Country's struggle for freedom against the apartheid regime and by extension a continued symbol for the struggle against all subsequent types of social injustices.

Posture or the selection of a given pose in statues is critical to the general application of their commemorative value. The statues are representations of particular individuals whose physical body structures are known. The manner in which their posture is presented can therefore create psychological perceptions of strength, astuteness, weakness or indecisiveness. For example, President Kasavubu's sharp soldier's attention posture complete with a salute (Plate 16) depicts him as 'astute' and no-nonsense. Mandela's raised fist salute and walking posture (Plate $4 b$ ) depicts him as personally triumphant and resilient.

Aesthetic details of attire are also an integral part of the artistic commemorative essence of statues that relate to the individual subject. President Nkrumah (Plate 2a) is depicted adorned in the traditional Kente robe portraying him as a cultural icon and a man of the people. Captain Sankara (Plate 11a) is depicted in his usual military attire and beret portraying him as a committed revolutionary. King Sobhuza of Swaziland (Plate 7a) is depicted barefoot and clad in full traditional regalia portraying his absolute love for traditional ways. Iconography is an important artistic depictive tool and is used extensively in statues as public art. Examples of iconography are aptly depicted in nearly all the featured statues.

\section{Commemorative Statues and the Construction of National Unity}

Ideally, a statue of a unifying political figure that is well executed and bears likeness and all other physical qualities associated with the subject ought to enhance the innate sense of 
national unity in any given country. This is in circumstances where such a statue and other commemorative public art such as monuments bear a critically fundamental function through which concepts of national history, pride and identity are concretized. This is of course explained from the perspective of those who wield hegemonic authority and resources to initiate and fund such statues. People "with political power within a given society organize public space to convey (and thus to teach the public) desired political lessons" (Levinson, 2018, p. 7). The word unifying is critical here because there must be a consensus that the subject of commemoration, in his/her lifetime, possessed an enduring unifying quality strong enough to have been moulded into a legacy that commemoratively is both symbolic and celebratory. But that is where the niceties end. In many countries, national unity is elusive and most are usually politically divided to varying degrees. It has been observed that some of the most revered political figures have also, in some instances, been the most polarizing making the notion of National unity not only a mirage but also difficult to define. Ethnicity is one major factor that contributes to political disunity and hence keeps National unity at bay. Given the way ethnicity manifests itself and subsequently plays out, it becomes increasingly difficult to delink it from the noble concept of commemoration since commemoration then also becomes selective and biased. Statues, for example, no matter how well-meaning they initially are, become embroidered in the 'politics of memory' and their essence is mired in commemorative controversy.

Levinson (2018) observes that "States always promote privileged narratives of the national experience and thus attempt to form a particular kind of national consciousness, yet it is obvious that there is rarely a placid consensus from which the state may draw" (p. 7-8). Works of art such as statues though physically visible, then become commemoratively redundant with no impetus whatsoever of spurring a modicum of national unity because the circumstances within which they are viewed are constantly shifting and narratives themselves are very fluid. Hence instead of promoting a sense of national unity, they themselves exist in a state of conflict and become instruments of the propagation of social/political discord

Another impediment in the construction of the concept of national unity through statues in Africa is the emotive nature of responses to some of the statues themselves. This is in regard to the political history surrounding the subjects of commemoration and their actions that may have greatly hurt or disadvantaged parts of the citizenry. The demand, therefore, shifts from the heroic understanding of national identity perpetuated by the sponsors of the statues to a form of 'counter-memorial'. This countermemorial culture focuses instead on the victims of historical/political injustices meted out before or during the reign of the subject of commemoration, all done in the name of the Nation or revolution or whatever the national motivation may have been at the time. Recent times "have been marked by a shift toward memorial practices that seek to move away from avowedly heroic understandings of national identity, for example, by acknowledging the victims of historical crimes perpetrated in the name of the nation" (Bull \& Clarke, 2020, p. 1). This query culminates in a commemorative impasse where a significant section of the audience (or wider society) feels that the statues neither represent their aspirations, definition or understanding of historical events, nor do they recognize their suffering. Subsequently, they instead cause commensurate anguish far removed from the notion of National unity. This school of approach has even developed further in some countries into avid activism and public contestations leading to the clamour for the removal of some of these statues and monuments altogether. 
In the peculiar African mode of politics, how then can statues be used to foster national unity? It is apparent that no single statue of a political figure may be able to attract the necessary commemorative clout to galvanize the audience and the larger populace to embrace National unity. It implies that the statues remain an anathema rather than a catalyst to national cohesion and unity. The nature of the African mode of politics demarcates people into enclaves of loyalty, be it ethnic or regional. People believe in the exclusivity of the notion of 'their' person, and if their person is not featured in national commemoration, then they fail to develop a sense of national belonging. This is compounded by the fact that statues are placed only in large metropolitan spaces where a large number of people do not actually view them in the first place. It may be that statues may 'cluster together' to present a united front in a 'garden of peace' to project the notion of national unity; this way a greater number of people may feel that 'their person' is present. Another way would be to decentralize statues such that certain political figures are commemorated in their nearest home towns or cities akin to some kind of homecoming.

\section{ANALYTICAL FRAMEWORK}

In order to capture the holistic essence of the statues featured, which are all statues of political leaders, this paper delves into the aesthetic qualities of each statue; how each has been executed and whether through that execution or rendition, it has achieved first and foremost the physical 'likeness' of the subject, which is fundamental to the appeal and acceptability of the statue itself. Style and use of materials, textures, depiction of attire and other personal items or iconography, posture, body proportion itself, gesture, movement and facial expression all form part of the aesthetic qualities since they have a direct bearing upon the holistic realism of the work. The aesthetic quality of the statue is complemented by the examination of the spatial placement and presentation of the statue in its environment, including mounting on the plinth and how it blends with that environment and communicates with the passing audience.

Each statue is also examined in terms of its symbolism. Symbolism as a tool for analysis of statues is particularly critical; it is what a statue symbolizes beyond its likeness appeal and the extent to which it bears symbolism upon which people can derive or clarify meaning. The extent to which a statue is able to display symbolism is commensurate to the extent to which it is able to communicate a profound message. There is symbolism in gesture, posture, body attire, facial expression and iconography. All these contribute to the holistic essence and meaning of the statue in terms of what the transient audiences derive from viewing the statue at any given time when they pose and interact with the statue. A statue, of course, cannot itself bear symbolism on its own accord since it is not a living character; it is only a vehicle for the depiction of symbolism.

Symbolism is derived from the actions, pronouncements, or content of the character of the subject of commemoration. For example, in the statue of King Sobhuza II of Swaziland (Plate $7 a$ ), the symbolism of the traditional attire and the three feathers depicted in the statue is derived from the fact that the King himself used to actually wear them in real life, in order to 'symbolize' his personal celebration of traditional culture and identity of his people. The static visual symbolism in a statue is, therefore, an extension of the inherent symbolism contained in the character of the subject that underscores a certain phenomenon. The 'Forward March' movement symbolized statically in the statue of Kwame Nkrumah in Accra, Ghana (Plate 2a) is itself depictive of the symbolism of his 'rallying call' for the urgency in the quest for the development of Ghana, the great leap forward into a brighter future in the immediate post-independence period. The static symbolism of Jomo Kenyatta 
grasping, or ostensibly waving his famous flywhisk high above his head, contained in his statue at Parliament buildings, Nairobi, Kenya (Plate $1 b$ ), is not accidental or just a postural embellishment; it is expressive of the rallying call 'Harambee' which symbolizes 'pulling together' for National development. This was an action he was famous for, that underscored his awareness of the need for the Country to always move forward and address challenges in unison, basically meaning that when people pulled together, no challenge was insurmountable.

This paper examines the statues of political leaders and hence the political relevance of a statue is important as a focus of analysis. Political relevance refers to the extent to which the statue spurs political debate and the kind of narrative attached to its presence. It will be observed that there are statues that are politically emotive, some are euphoric and celebratory, some are inspirational perhaps and yet others while not necessarily despised, generate a completely different type of narrative; that of neo-resistance and questioning the 'political legacy' of the subject altogether in view of the contemporary context.

\section{Criteria for Commemoration}

In the context of this paper that focuses on the artistic commemoration of political leaders in Africa, there is probably no prescribed universal criteria for commemoration of leaders or iconic figures since that would draw too much controversy. It has already been observed that statues themselves already attract underlying political and emotive sensitivities that often prevent rational or pragmatic interrogation of individual subjects beyond certain demarcation lines. It is, therefore, left to respective countries to decide who 'deserves' rather than who 'qualifies' to be commemorated. However, some of the most considered criteria for commemoration are personal integrity, selflessness, accomplishments and holistic content of character.

Integrity: This is a trait by which a leader, in this case, a political leader, is expected to always act, guided by forthrightness and a high degree of honesty. According to Schlenker (2008), “integrity involves honesty, trustworthiness, fidelity in keeping one's word and obligations, and incorruptibility, or an unwillingness to violate principles regardless of the temptations, costs, and preferences of others." Political leaders have often flouted this and acted instead according to their own dictates and whims guided generally by no ethical boundaries. Schlenker further observes in his model that the opposite of integrity is expediency, which involves:

The idea that principles can and should be tailored to fit the context, that it is important to take advantage of profitable opportunities and foolish to fail to do so, and that deviations from principles can usually be justified (Schlenker, 2008, p. 1080).

Selflessness: This is a complex and often tricky trait to define. This is because it is first and foremost deeply personal; which means that it is intrinsically present in some people by virtue of their individual genetics and completely absent in others. It is, therefore, firmly and uniquely ingrained in character and cannot be pretended. Most people treat selflessness as something they can put on display, like a great façade and withdraw it when it does not suit their purpose. It is intricately intertwined with compassion which is also engrained in character; the two, therefore, have a symbiotic association. When one possesses compassion, it is most likely that he or she will willingly engage in acts, decisions and activities that are selfless. Selflessness cannot manifest or even truly exist in an environment where compassion is absent or lacking. Selflessness has been described as encompassing compassion and empathy; of acting deliberately from the 
motivation of doing the right thing and making decisions that will most likely culminate in benefiting the majority of fellow human beings in prescribed circumstances. A fundamental and perhaps controversial tenet of selflessness is the de-emphasis or removal of 'self-interest' where one focuses on the wellbeing of others without expecting or desiring compensation or reward. Becker (2014) observes that;

Our lives can be lived for any number of purposes. They can be used to advance a personal kingdom for selfish reasons (money, possessions, fame, prestige, reputation). But our lives can also be lived for the pursuit of justice, happiness, or growth for another person or people group. We can live to solve the problems we encounter in this world. We can dedicate ourselves to advancing certain ideals. But only when we embrace service and selflessness will we find lasting significance in our world.

When the notion of selflessness is observed alongside the perceived interests of political leaders, then a problem of conflict of virtue tends to emerge. It is in this context that the legacy of individual political leaders is interrogated. The conflict appears in the way people, including political leaders, define success or exist in the bubble of their vanity. Becker (2014) further notes;

Many will try to define success in terms of winning out over others, having power over others, or the ability to dominate others. The lust for power is common and widespread in humans - the power to order others around, the power to make decisions that will impact others, and the power to own when others cannot.
Content of character: The phrase 'content of their character' was popularized within the context of moral themes contained in the speech I have a dream by Dr. Martin Luther King Jr., delivered in August 1963. In the now-famous part of the speech, Dr. King proclaimed;

I have a dream that my four little children will one day live in a nation where they will not be judged by the colour of their skin, but by the content of their character.

The phrase still attracts debate about its real contextual meaning. According to Robinson (2020), it is, however, acknowledged that Dr. King paid great attentiveness to character which comprised an essential focus of his philosophy of education. This paper contends that in leadership, 'content of character' has been used as a holistic tool to interrogate the individual essence of the character of leaders in terms of their behaviour, personal conduct and their attentiveness to decisions and acts that culminate in the public good. This subsequently becomes an integral part of their legacies, since it is a panacea for the appreciation, observance and respect for liberty and justice for all. It is, hence, assumed that leaders whose 'content of character' is held in doubt mainly by actions that undermine their moral authority to lead their people become disqualified for commemoration. In reflecting upon what Dr. King meant as well as the fundamental perspective from which this paper contextualizes the content of character of leaders, Henriques (2016) sums it adequately when he observes in reference to content of character;

This refers to the core ethical values of honesty and integrity, respecting others, taking responsibility for one's actions, being 
East African Journal of Interdisciplinary Studies, Volume 3, Issue 1, 2021

Article DOI: https://doi.org/10.37284/eajis.3.1.295

fair and just, and being someone who promotes love and compassion in others. We can also think about the content of character in terms of core virtues and the extent to which one embodies wisdom, humility, courage, justice, temperance, and the value of human dignity

Content of character therefore cannot be trivialized. It can be said that character plays a significant role in the politics of a political leader which in turn affects the fate of people, the destinies of Nations and the outcome of events that shape history. In this regard, the performance of political government during the duration of its rule, against which the quality of life of its citizenry is measured can be attributable to a great extent, to the character of its political leader.

\section{ANALYSIS OF WORK}

\section{Jomo Kenyatta}

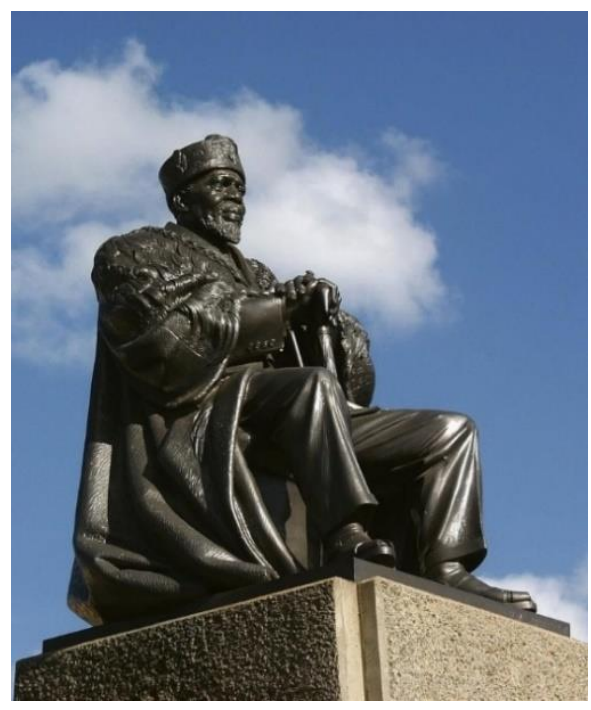

Plate 1a: Jomo Kenyatta, Kenya Source: Africa Is a Country

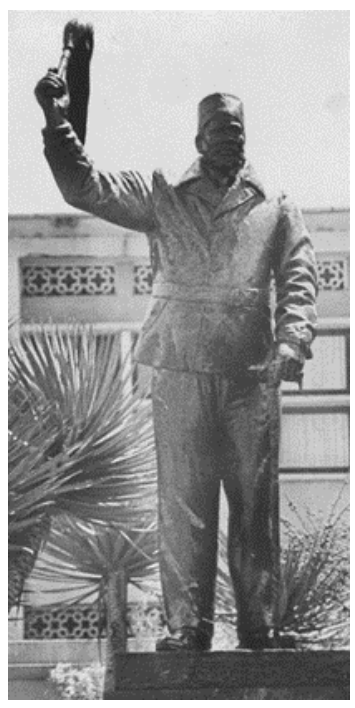

Plate 1b. Kenyatta Source:Opendemocracy

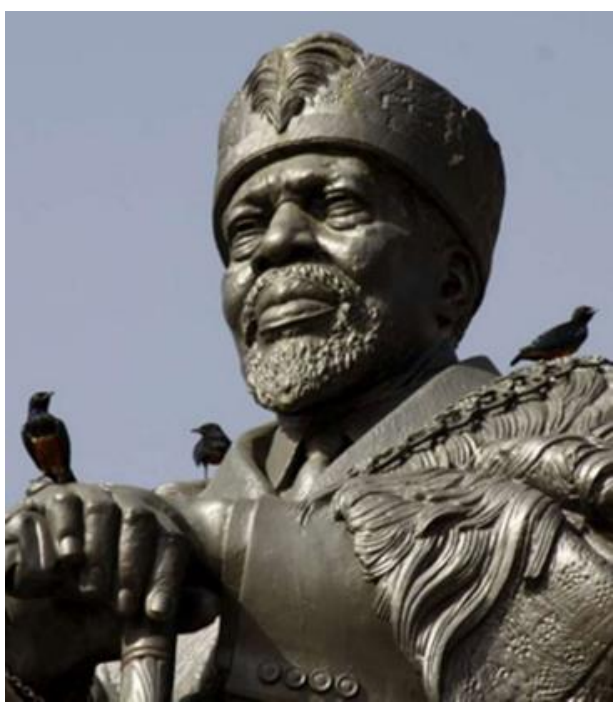

Plate 1c. Pres. Kenyatta, Close-up Source: Nation.Africa/Twitter

Mzee Jomo Kenyatta was a Kenyan Prime Minister of Kenya from 1963 to 1964 and Independence hero who served as the first subsequently became the first President of the 
Republic of Kenya from December 1964 to August 1978. He also led the Kenya African National Union (KANU) party from 1961 to 1978. Charismatic and well-schooled, he became one of the most influential African leaders during his presidency. Kenya achieved substantial transformation during his tenure in the education, health, infrastructure and economic sectors as well as the Africanization and consolidation of government. He was, however, accused of being dictatorial, authoritarian and intolerant of dissent. He died in office on August 22, 1978 aged 89.

The statue of Mzee Jomo Kenyatta (Plate 1a) was unveiled in 1973 during the $10^{\text {th }}$ anniversary of Kenya's Independence and is located at the International Conference Centre in Nairobi. The 12-foot seated bronze statue of Mzee Kenyatta was created in England by James Butler and shipped to Nairobi and erected at the site. It depicts the late President in a pensive pose, wearing a ceremonial robe and cap and resting his hands on his walking stick with his famous

\section{Kwame Nkrumah}

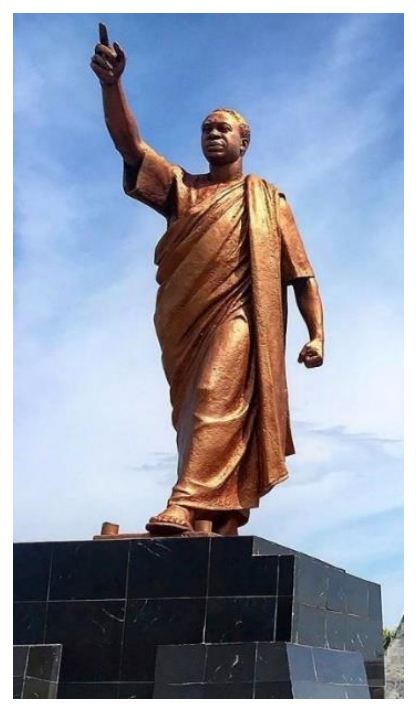

Plate 2a: President Kwame Nkrumah flywhisk hanging from his arm. He is also wearing his beloved sandals. The facial likeness (Plate 1c) is accurate and body posture and proportions well-articulated and finished to very fine details; the statue is a remarkable representation of the image and description of Mzee Kenyatta. It is mounted on a very high plinth. "It has that quality of ageing with grace, the bronze darkened and finely sculpted to the founding fathers almost daunting resemblance" (Seda, 2015.)

Another outstanding statue (Plate 1b) was erected in 1963 at Parliament buildings, Nairobi and depicts the late President standing tall 'waving' his flywhisk and holding his walking stick. The imposing statue also features his famous leather jacket which is symbolic of the day of his arrest on $20^{\text {th }}$ October, 1952 upon the declaration of the state of emergency in Kenya. His facial likeness is accurate and body posture and structural representation are also well articulated with convincing details.

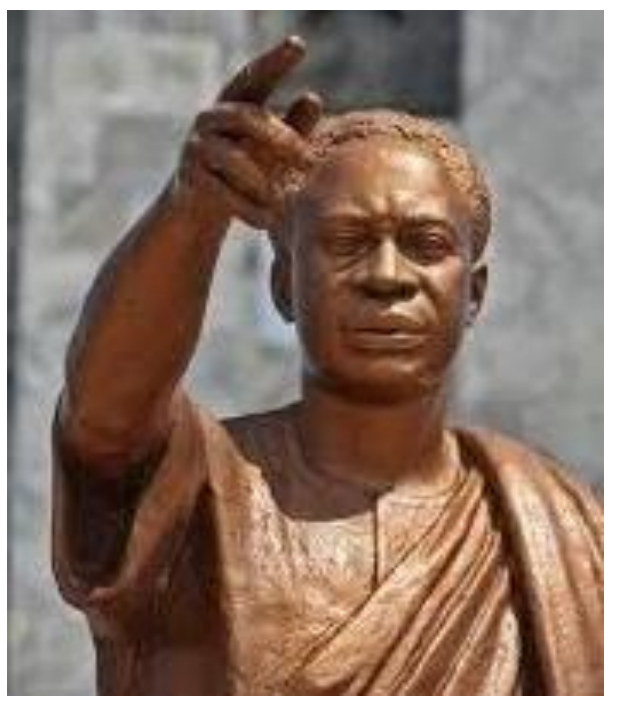

Plate 2b: President Nkrumah - Ghana, Closeup 
Source: Twitter

Osagyefo Dr. Kwame Nkrumah was a Ghanaian politician and revolutionary leader who went on to become the first Prime Minister from 1957 to 1960 and President of the Republic of Ghana from 1960 to 1966. He earlier served as Prime Minister of the Gold Coast from 1952 to 1957 before leading his country to Independence from Britain in 1957, becoming the first African former British colony to achieve that milestone. He was also a pioneering Pan Africanist and founding member of the Organization of African Unity (now the African Union) which he helped establish in 1963. He embarked on initiatives to rapidly develop Ghana as well as engage the rest of Africa and the world. He was credited with the development of education through his Seven-Year Development Plan for National Reconstruction and Development which focused on education as a key driver of development. He generally followed a socialist path and was increasingly critical of capitalism and its effect on Africa's holistic growth and development. He was, however, criticized for becoming increasingly intolerant of opposition and leading Ghana towards the path of dictatorship through one-party rule and a heavily orchestrated personality cult. 'The basis of Nkrumah's personality projection was a somewhat vague philosophical notion called Nkrumaism' (Monfils, 1977, p. 326). President Nkrumah was overthrown in a military coup d'état in February 1966 while on a state visit to South Vietnam. He proceeded to exile in Conakry, Guinea where he lived until his death in a hospital in Bucharest, Romania on $27^{\text {th }}$ April, 1972, aged 62. September 16 is
Source: Travel adventures

designated Kwame Nkrumah Memorial Day to celebrate his legacy.

Nkrumah's golden bronze statue (Plate 2a) is located within the Kwame Nkrumah Memorial Park located in central Accra, Ghana. The statue which was unveiled in July 1992, marked the full rehabilitation of Nkrumah and was the first major public commemoration of his legacy since the coup in 1966. It depicts Nkrumah as energetic and resolute (Plate 2b); the forward pointing gesture is based on the slogan of his political party, the Convention People's Party (CPP) that states, "We face neither East nor West, we face forward. Forward ever, backward never." He is depicted adorned with the traditional attire, the royal Kente robe, which he was fond of wearing during certain ceremonial occasions in his quest to project himself as a man of the people or a traditional chief. "Indeed, Nkrumah used dress as an aspect of the creation of a certain type of mood within a rhetorical setting" (Monfils, 1977, p. 315). It is significant that the statue is accompanied by a host of other gestural statues of Asante elephant-horn blowers whose symbolism is clear; to ostensibly create the impression of the presence of royalty. An earlier statue of Nkrumah that was located in parliament buildings was vandalized during the coup that ousted him in 1966, which is symbolic of the ironic fate of statues when the leaders leave power in certain circumstances. It was re-erected, still headless, but with the head placed beside it, at the Kwame Nkrumah Memorial Park in 2007. 


\section{Samora Machel}

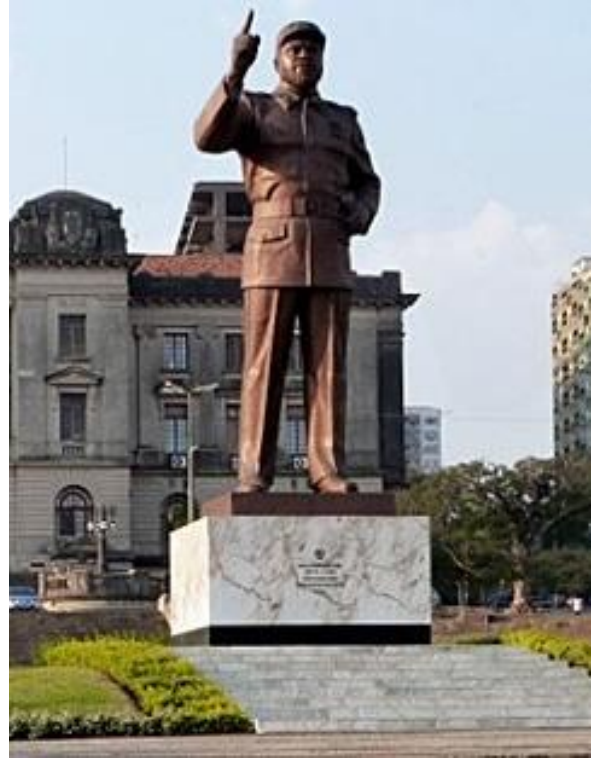

Plate 3a: President Samora Machel Source: Deutschlandfunk Kultur

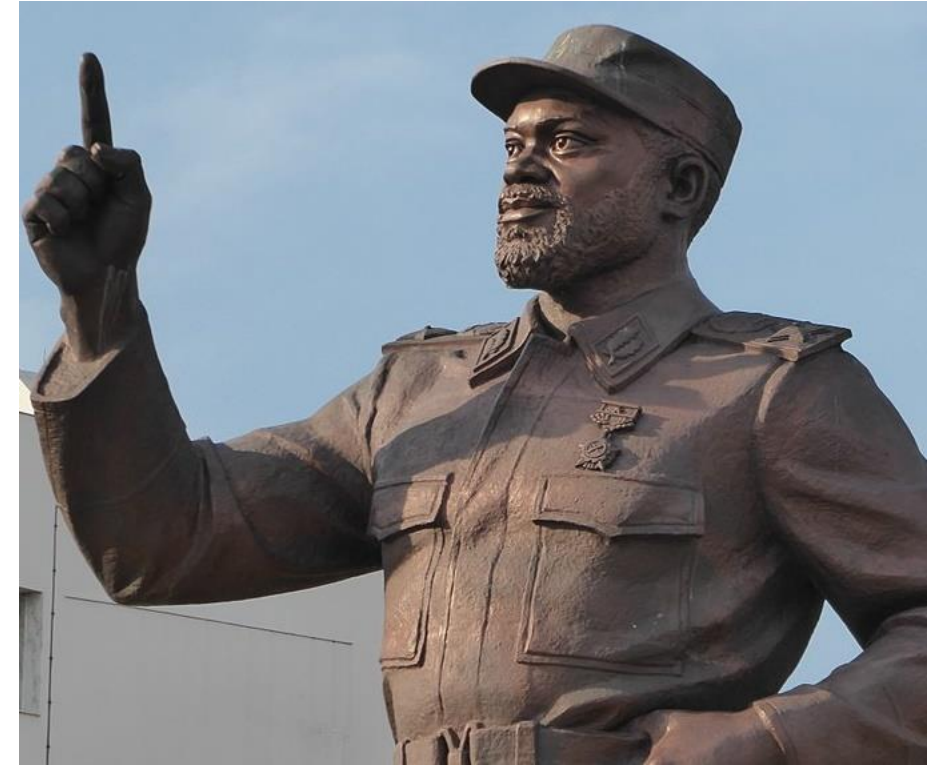

Plate 3b: President Machel - Mozambique, Closeup Source: Commons. Wikimedia. org
Samora Moises Machel was a Mozambican military leader, revolutionary and independence hero who served as the first President of the Republic of Mozambique from 1975 to 1986. Machel became the head of Frelimo (Frente de Libertação Moçambique) the political and military movement of Mozambique in 1970 after the assassination of its leader, Eduardo Mondlane, in 1969. After a sustained guerrilla war waged by Frelimo forces, Mozambique attained independence from Portugal in 1975. He subsequently leaned towards a Marxist-Leninist ideology, nationalizing land and pursuing collective agriculture. Economic development was, however, greatly hampered by a postindependence insurgency carried out by Renamo, a dissident group, which started in 1977 and quickly degenerated into a full-scale civil war. A peace agreement was not reached until 1992, six years after the death of Machel.
President Machel died in a plane crash at Buzini, just inside South Africa on his way back to Mozambique from a regional summit in Zambia on $19^{\text {th }}$ October, 1986 aged 53.

The Samora Machel 9.5 metres 4.8-ton bronze statue (Plate 3a) located in Maputo, Mozambique was constructed in North Korea and inaugurated in October 2011 during the $25^{\text {th }}$ anniversary of his death. Mounted on a 2.9 metre marble plinth, it depicts the former President and independence hero holding out his hand with a one-finger salute. His attire is a ceremonial military uniform with cap (Plate 3b) that was signature wear for Marxist leaning leaders at the time. The statue has, however, been criticized for having little resemblance to President Machel and the body seems to depict the subject as appearing taller than he was in real life. 


\section{Nelson Mandela}

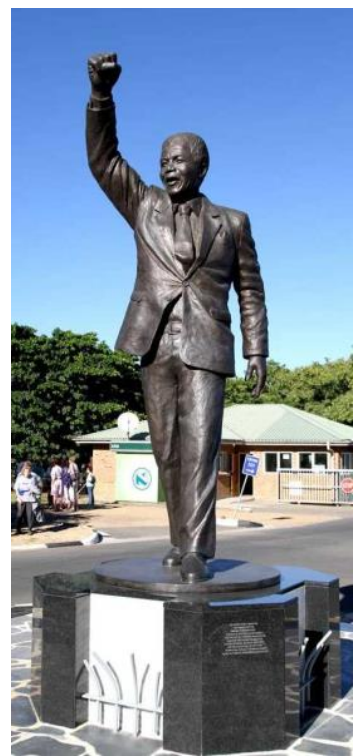

Plate 4a: President Nelson Mandela Source: Weburbanist.com

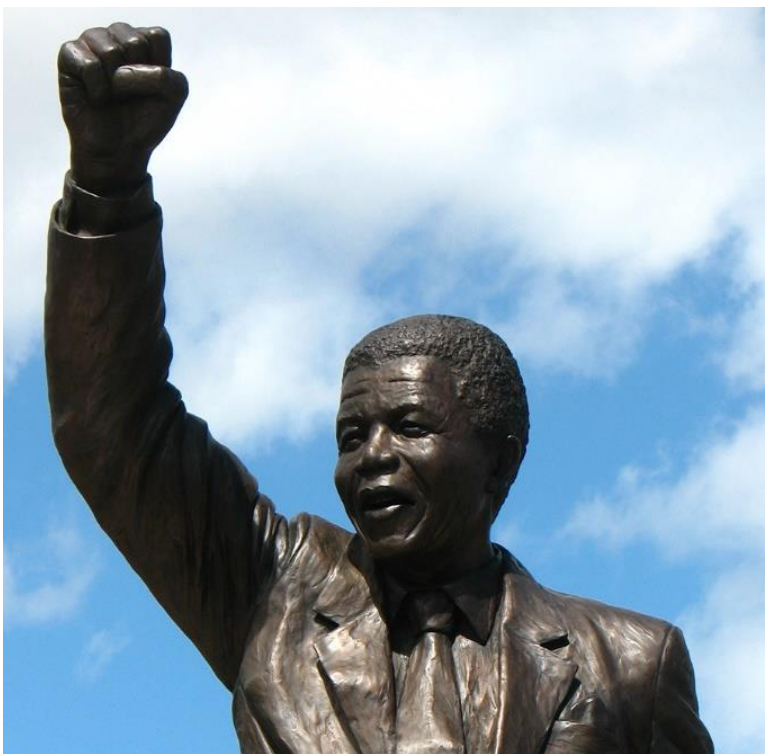

Plate 4b: President Mandela - South Africa, Closeup Source: i24News.tv
Nelson Mandela was a South African antiapartheid hero and revolutionary who was the first President of the Republic of South Africa from 1994 to 1999 . He was the first black President and also the first democratically elected President through universal suffrage. He was also President of the African National Congress (ANC) from 1991 to 1997. He became a world icon for his relentless struggle against the Apartheid regime, for the pursuit of freedom and social justice as well as his immense personal sacrifice. He spent 27 years in prison and upon his release in 1990 led the clamour for a free and democratic South Africa that culminated in the first multi-party elections in 1994. He was subsequently elected President and served for one term, voluntarily leaving office in 1999. He was renowned for his unique humanism and love for fellow human beings and despite his great suffering and long incarceration, he showed no bitterness and went on to lead a multi-racial and democratic South African in what became known as the Rainbow Nation. He received numerous awards and received the Nobel Peace Prize together with F.W. de Klerk. Madiba as he was fondly referred to, remains greatly revered in South Africa and the world over. He died on $5^{\text {th }}$ December, 2013 aged 95.

This bronze statue of Nelson Mandela (Plate 4a) is located outside the Drakenstein Correctional Centre (formerly Victor Verster Prison) in Paarl, near Cape town and commemorates his own freedom after being released from prison in February 1990. It was unveiled in August 2008 and was undertaken by Jean Doyle, a South African sculptor. The statue (Plate 4b) depicts a jubilant Mandela walking his first steps into freedom, with his fist salute and broad smile, which was a remarkable event after a long period of incarceration. Mandela spent his last 14 months in this prison before his release. The statue rests on a medium-sized six-sided black marble plinth. 


\section{Julius Nyerere}

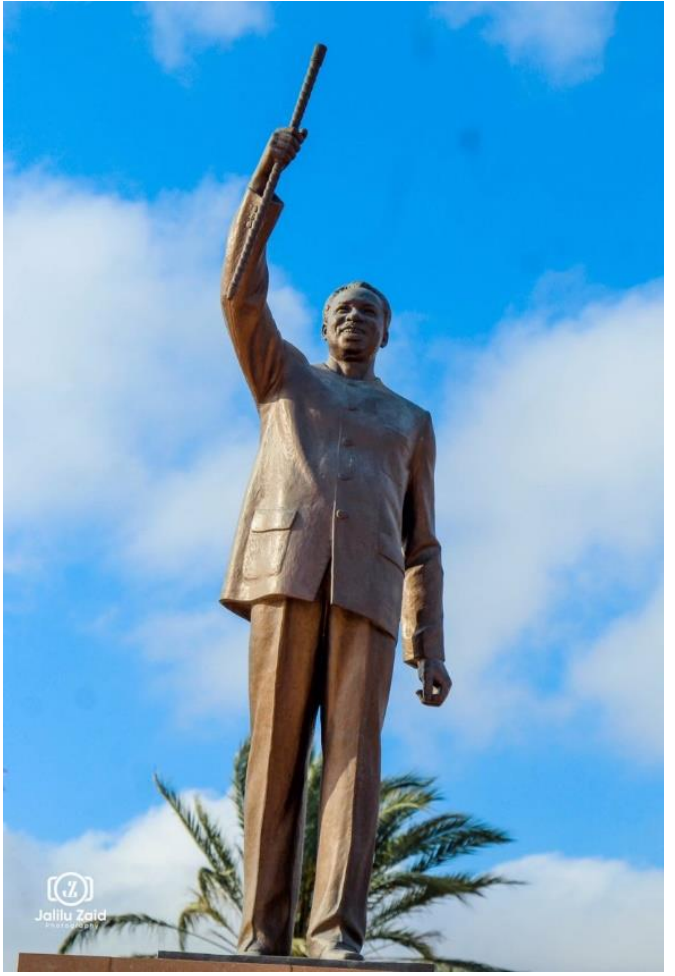

Plate 5a: President Julius Nyerere

Source: Twitter.com

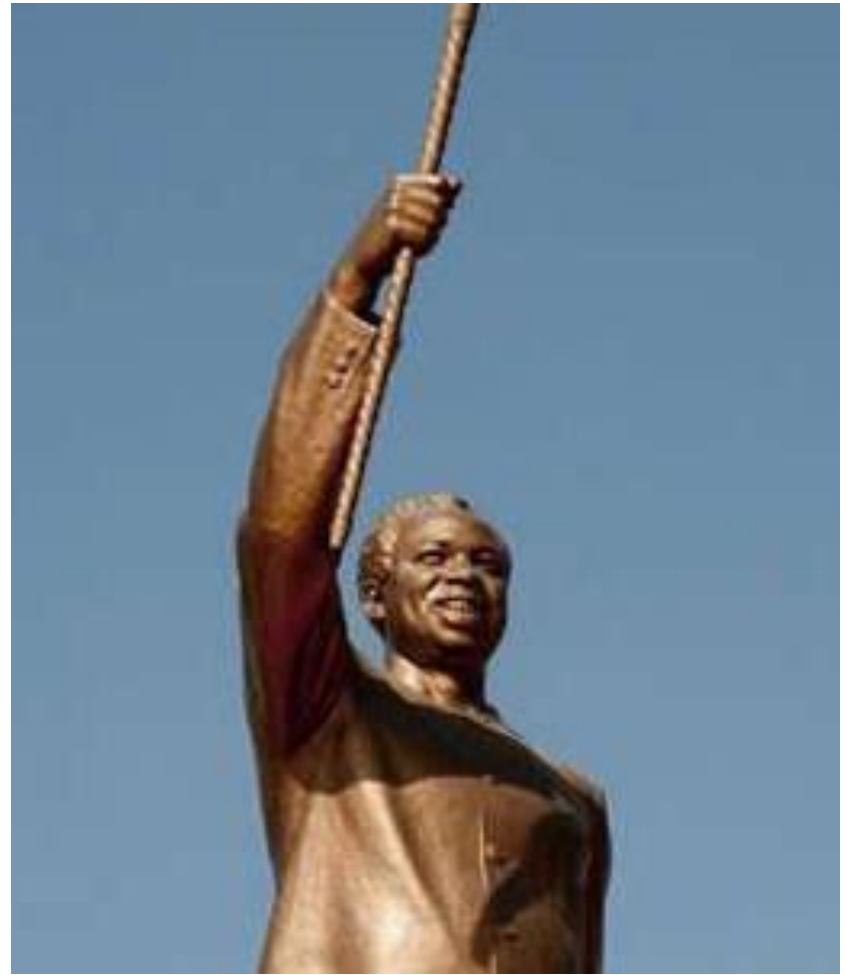

Plate 5b: President Nyerere - Tanzania, Closeup Source: Wikimedia commons
Julius Kambarage Nyerere was a Tanzanian independence leader and politician who became the first Prime Minister of Tanganyika between 1961 and 1962. He was briefly the President of Tanganyika between 1963 and 1964 before becoming President of the United Republic of Tanzania from 1964 to 1985, upon the unification with Zanzibar. He was a founding member of the Tanzania African National Union (TANU) from its formal inception in 1954, which later became 'Chama Cha Mapinduzi' in 1977. He oversaw the unification with Zanzibar in 1964. He pursued a socialist path that was contained in the Arusha Declaration of 1967 which embraced a socialist ideology based on the development of the peasant agricultural economy known as 'Ujamaa'. President Nyerere was instrumental in the ousting of Uganda's dictator Idi Amin in a brief but costly war with Uganda in 1979 . He was respected for his intellectualism and was a key figure in the liberation movements of many Southern African countries. He voluntarily left office in 1985 setting a firm path of electoral democracy. He died in London on $14^{\text {th }}$ October, 1999 aged 77.

The North Korean made bronze statue of President Nyerere (Plate 5a) is located within Nyerere Square in Dodoma, Tanzania. It was unveiled in 2005. The statue depicts the late President holding up his baton that signified his authority and leadership. He is depicted smiling broadly and wearing his simple African collar-less suit (Plate 5b) for which he was famous for in later years. The statue, however, depicts him as a little big-bodied and slightly tall. President Nyerere was slim and slight bodied and appeared very unassuming. He did not welcome the idea of statues created for him which was in keeping with his 
East African Journal of Interdisciplinary Studies, Volume 3, Issue 1, 2021

Article DOI: https://doi.org/10.37284/eajis.3.1.295

personal modesty and abhorrence of building a cult of personality around him.

\section{Nnamdi Azikiwe}

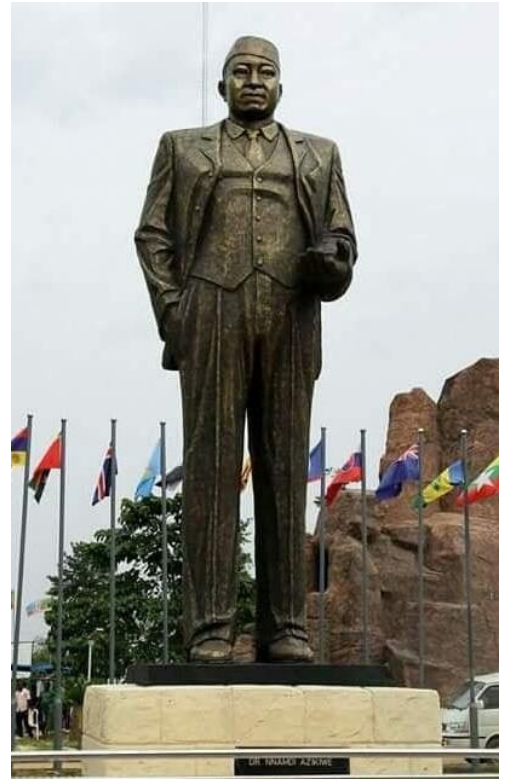

Plate 6a: President Nnamdi Azikiwe Source: IMO state blog

Nnamdi Azikiwe was a Nigerian politician and statesman who served as the first President of the Federal Republic of Nigeria from 1963 to 1966. He also served as the first President of the Nigerian Senate in 1960 and went on to become the third Governor-general of Nigeria from 1960 to 1963 . He was also the first Nigerian to be named in the Privy Council of the United Kingdom, a formal advisory body to the Sovereign of United Kingdom. After only two years and three months in power, he was ousted in a military coup together with his Prime Minister, Sir Abubakar Tafawa Balewa in January 1966. He later served as Chancellor of the University of Lagos and mounted two unsuccessful bids for the presidency in 1979 and 1983. He died on $11^{\text {th }}$ May, 1996 aged 91.

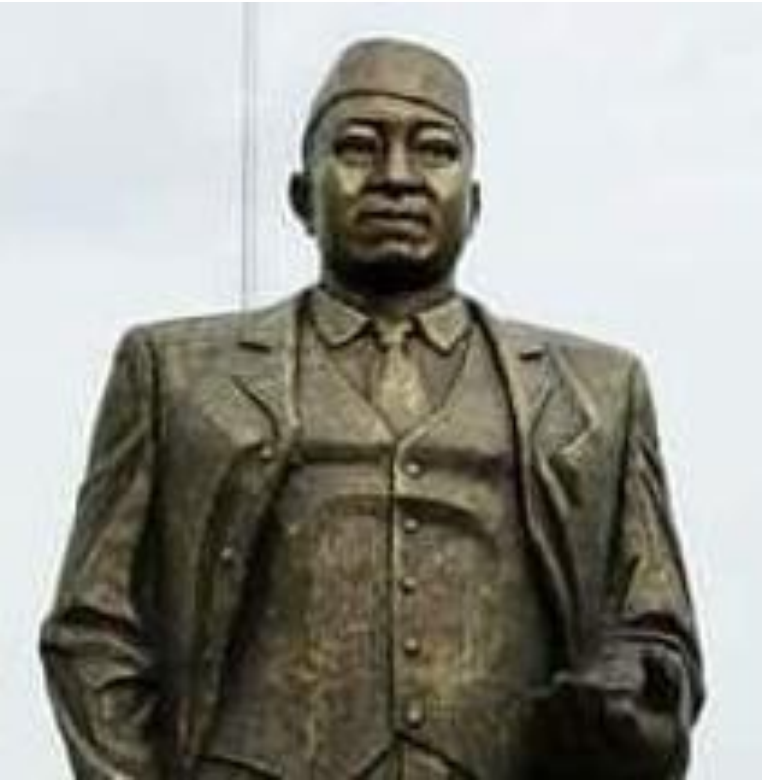

Plate 6b: President Azikiwe - Nigeria, Closeup Source: IMO state blog

His statue (Plate 6a) is located at the Hero's Square in Owerri, Imo State. It was unveiled on $17^{\text {th }}$ December, 2018 and depicts him wearing a three-piece suit as well as a traditional Nigerian head cap (Plate 6b). It is one of a series of other statues erected in Imo State that were criticised for their lack of likeness to their subjects of commemoration and for not being a priority for the State at the time. Another statue of Azikiwe which had been erected in his hometown of Onitsha in Anambra State was destroyed by angry youths in October 2020. The mob accused the late leader of being the cause of their problems by championing a unified Nigeria. 


\section{King Sobhuza II}

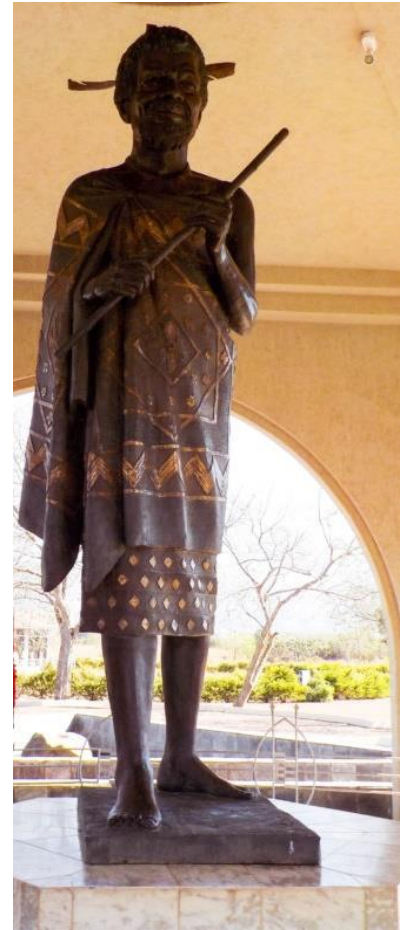

Plate 7a: King Sobhuza II

Source: Marshmallow travels

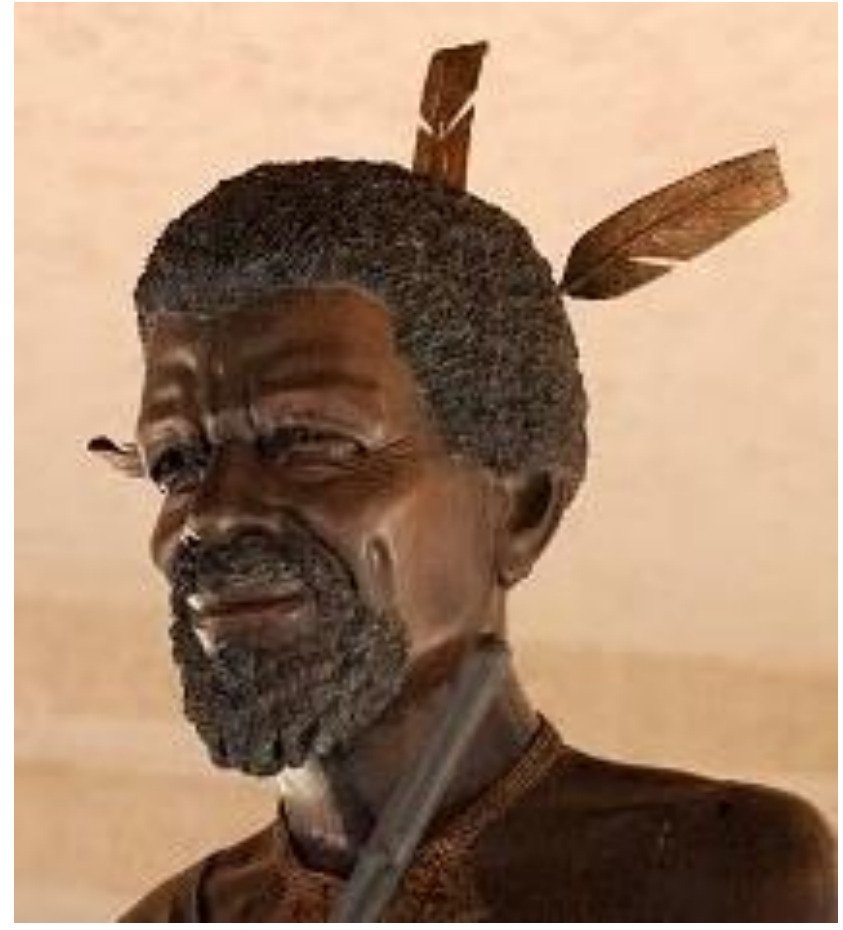

Plate 7b: King Sobhuza II-Swaziland, Closeup Source: Aubrey Groves -Blogger
King Sobhuza II was the King of Swaziland (now Eswatini since 2018) who reigned for just over 82 years from the age of 1, making him the longest-reigning monarch in the world. He became King after the death of his father King Ngwane V in 1899. He received formal education and initially reigned through a regent, eventually commencing his rule in 1921 . He led his tiny Kingdom to independence from Britain in 1968 and was known for his pragmatism and simple life. During his rule, he proved skilful in managing to merge tribal traditional expectations on one hand and modern social/economic pragmatism on the other. Initially designated as a constitutional monarchy, he repealed the constitution in 1973 and abolished political parties enabling him to exercise power as an absolute monarch. A new constitution in 1978 provided for a new tribal Electoral College that comprised members selected by tribal councils. During his rule, he managed to resolve the thorny land issue that eventually brought large tracks of land which were owned by absentee foreigners back to indigenous ownership. He died on $21^{\text {st }}$ August 1982 aged 83 and was succeeded by King Mswati III.

The King's 10 feet bronze statue (Plate 7a) is located inside the memorial park dedicated in his honour. The face bears the likeness of the subject, with a mild smile and an almost inquisitive gaze. The body is adorned in traditional regalia including the barefooted King holding his staff, a symbol of royal authority, a beaded necklace and three eagle feathers (wearing feathers on the head is a distinguished symbol of Swazi cultural identity) all of which underscore the King's fondness for tribal traditions. The close-up (Plate 7b) shows the King's face in more detail depicting the piercing gaze and an almost enigmatic hidden smile. The face 
can be said to be a credible depiction of his facial likeness.

\section{Patrice Lumumba}

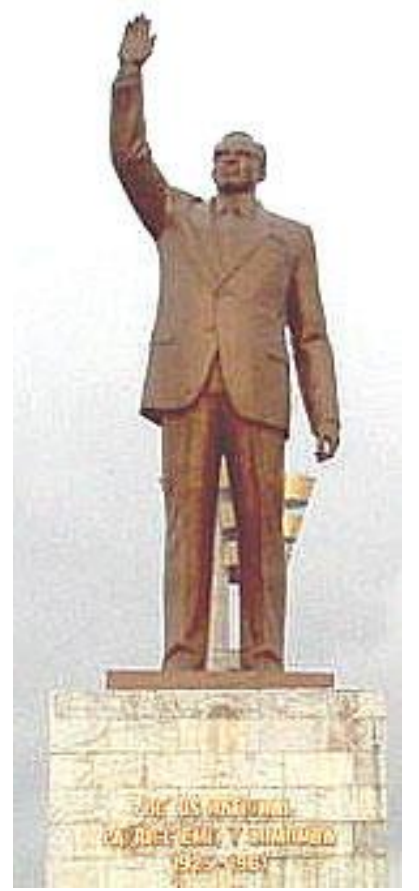

Plate 8a: Prime Minister Patrice Lumumba Source: Nijart.com

Patrice Lumumba was a Congolese independence leader and politician who was the first Prime Minister of the Democratic Republic of the Congo from June to September 1960. He was instrumental in trying to put together a functional administration and have the newly independent country find its footing. During the early stages of the Congo crisis that broke out in the months after independence that saw the secession of Katanga Province, among other problems, he unsuccessfully sought to stabilize the situation by seeking the intervention of the United States and the United Nations. He turned to the Soviet Union, an action that only aggravated the matter and put him on a collision course with Joseph Kasa-Vubu, the Country's first President and eventually with Joseph Mobutu, the Army Chief of Staff. This contact with the Soviet Union also raised suspicion that he had taken sides in the on-going cold war. He

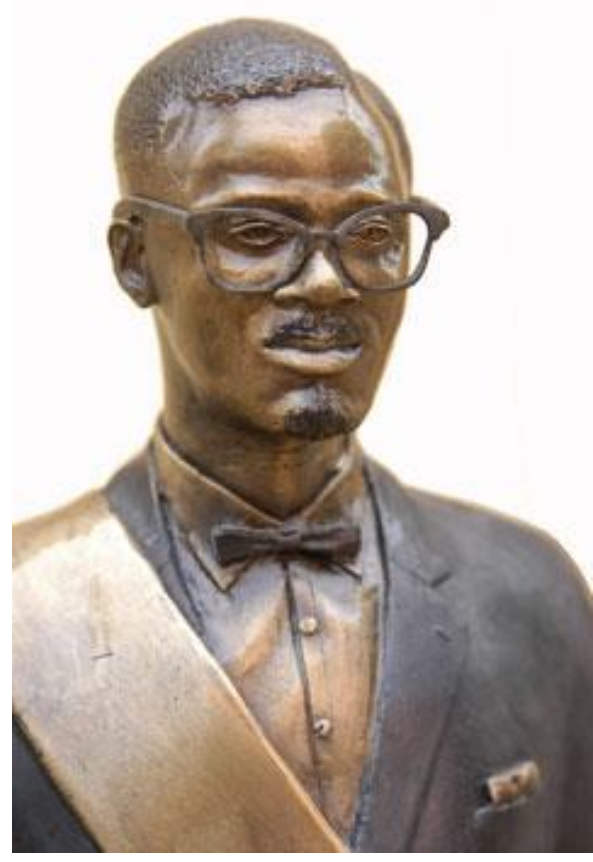

Plate 8b: Lumumba Monument Project-close up Source: Nijart.com

was dismissed as Prime Minister and after a protracted political tussle with Kasa-Vubu, and was eventually arrested by Mobutu's forces. He was handed over to Katanga's secessionist authorities and was subsequently assassinated by a firing squad in extremely controversial circumstances on $17^{\text {th }}$ January, 1961 aged 35 . Lumumba became, particularly because of the manner of this death, a martyr and symbol of Congolese nationalism, decolonization and the wider Pan-African movement.

His statue in Kinshasa (Plate 8a) was erected in January 2002. It depicts Lumumba with his hand upraised in an eternal wave. The North Korean made bronze statue has been criticised for not depicting the likeness of the late leader; he was tall and slender, not heavy-bodied; and the head hardly resembles the late Prime 
Minister. The Lumumba Monument Sculpture artist's proof edition by Nijel BPG (close-up, Plate 8b) is a significantly more accurate representation of the Prime Minister both in terms of facial likeness and body posture. According to Nigel's statue review on the Lumumba statue, "although it is a national monument, the artisans did not take the care to depict Lumumba as he was. He was tall, thin, and introspective. Instead, the heavy-bodied, salutory statue representing Patrice Lumumba may be a heroic representation of him, but far less than a true-to-life rendition."

\section{Seretse Khama}

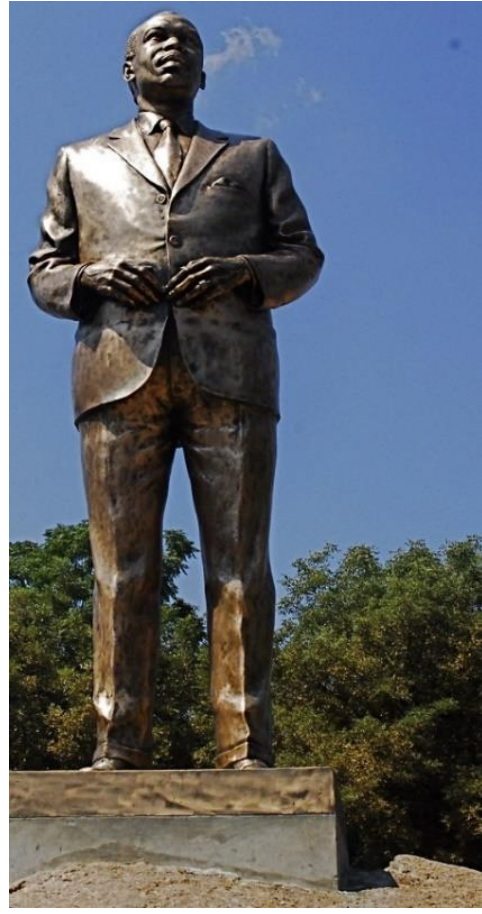

Plate 9a: Sir. Seretse Khama Source: Flickriver

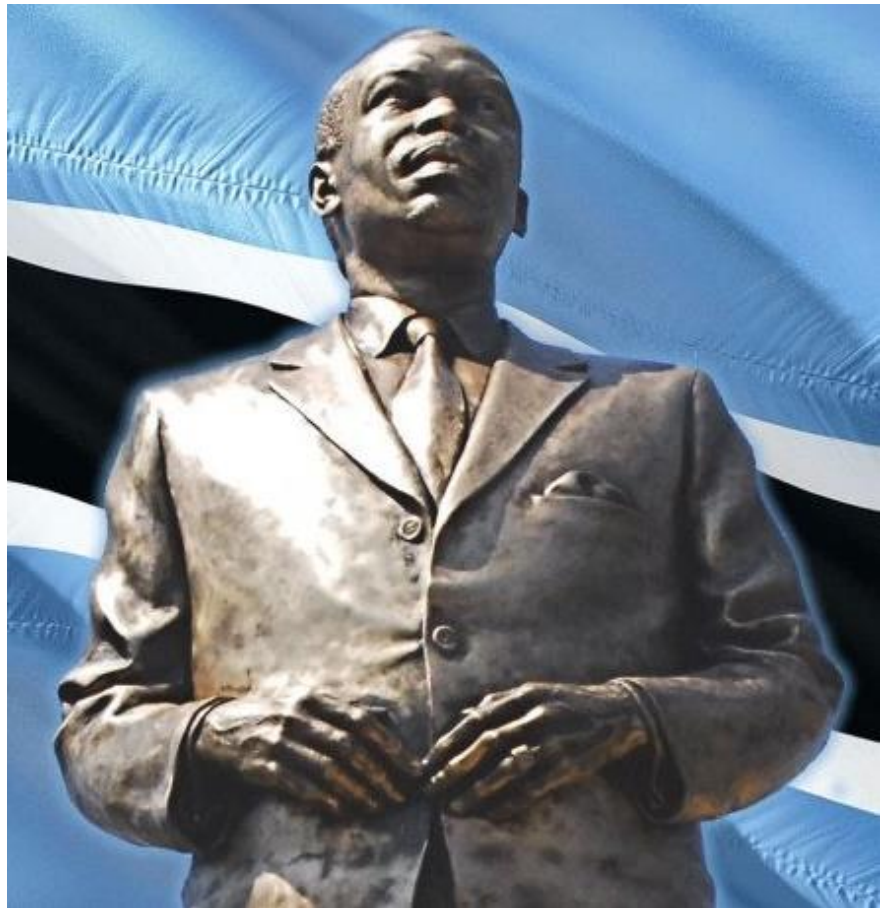

Plate 9b: President Sir. Seretse Khama - Botswana, Closeup Source: Office holidays
Sir Seretse Khama was the first President of the Republic of Botswana from 1966 to 1980. Taking over an almost desolate country with few educated people, low literacy levels and a non-existent infrastructure, he undertook vigorous economic reforms to spur economic growth and took early measures to curb corruption. At the time, Botswana was the second poorest country in the world. He embraced liberal democracy and non-racism making his country unique in a volatile region with racist regimes. Unlike his contemporaries, he avoided a Marxist path and pursued marketdriven policies including low taxes and lowincome tariffs. By the time of his death in 1980
Botswana had the fastest economic growth in the world, driven mainly by mining. Mining revenues allowed investment in education, health care and infrastructure. He initiated the Botswana Institute of Higher Education that led to the eventual establishment of the University of Botswana in 1982, after his death. He established the Botswana currency, Botswana Pula, in 1976 and the Botswana Defence Force in 1977. Khama is revered as an independent leader and founding father and also as a person who was uniquely dedicated to Botswana's development. He died on $13^{\text {th }}$ July 1980 aged 59. 
His bronze statue (Plate 9a) was installed in 1986 during the 20th anniversary of the independence of Botswana. It is located in front of the National Assembly in Gaborone, the capital of Botswana. It now faces parliament after a protracted controversy when it was turned 180 degrees to face west after initially facing east. The statue, made by British artist Norman Pearce, depicts the subject in a dignified yet reflective posture gazing up into the skies, dressed in a business suit (Plate 9b). Such skywardlooking poses are often designed to strike an 'optimistic' view of the future which is ultimately meant to be inspirational to viewers and passers-by. However, the statue remains controversial since some argue it does not bear a true resemblance to Khama (Seretse, 2008).

\section{Laurent Kabila}

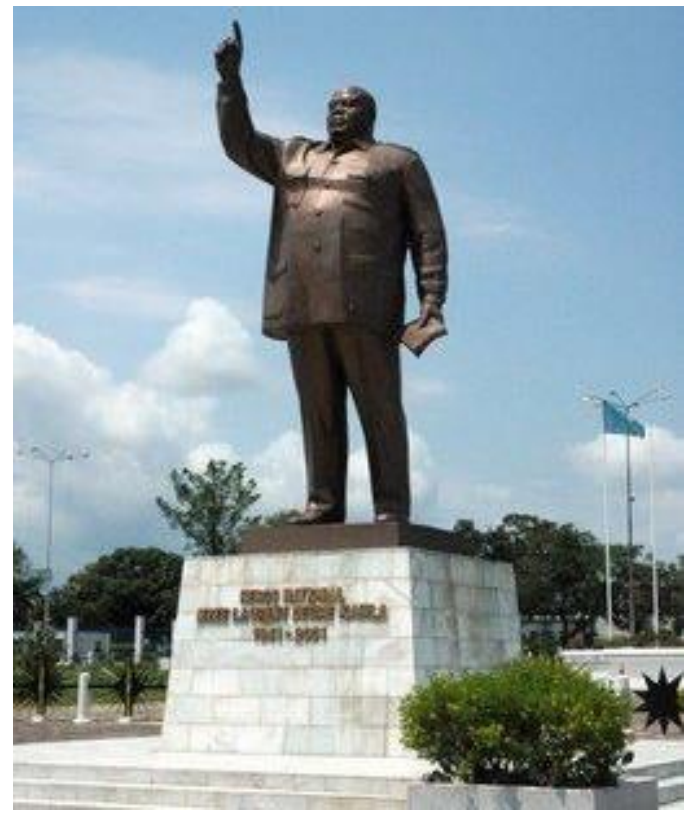

Plate 10a: President Laurent Kabila

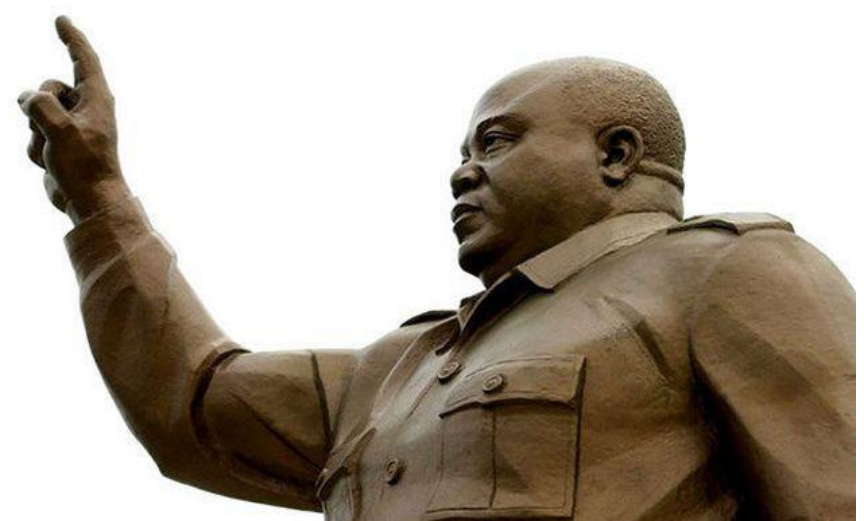

Plate 10b: President Laurent Kabila - DRC, Closeup

Source: 7sur7.be
Laurent Kabila was a Congolese revolutionary and politician who was the third President of the Democratic Republic of the Congo (DRC) from 1997 until his assassination in 2001. He became prominent by waging a relentless war against the regime of President Mobutu Sese Seko, in the first Congo war, eventually overthrowing him in 1997. Upon assuming power in 1997 he reverted the Country's name to the Democratic Republic of the Congo from the Republic of Zaire. Like most African revolutionaries, he initially embraced a Marxist ideology but later pursued a social-democratic path. He was, however, soon embroiled in the second Congo war that started in 1998 and peace negotiations were still going on at the time of his death. Mobutu's regime was so abhorred at the time of his departure that Kabila was perceived as a different kind of leader and was hence revered as a neo-liberation hero. However, his legacy is mixed mainly because he did not seem to have had the time to settle down to govern and was perceived as increasingly dictatorial. He was assassinated in his office on January 16, 2001, aged 61 .

The statue of Laurent Kabila (Plate 10a) is a North Korean made $25 \mathrm{ft}$ bronze 
monument located at the centre of Kinshasa, the capital of the DRC. Built-in 2002, the statue has been criticized for not depicting the body of the Congolese dictator; that perhaps he appears more like adorning the body and attire of a North Korean dictator than that of himself. However, it does not appear true that his body structure

\section{Thomas Sankara}

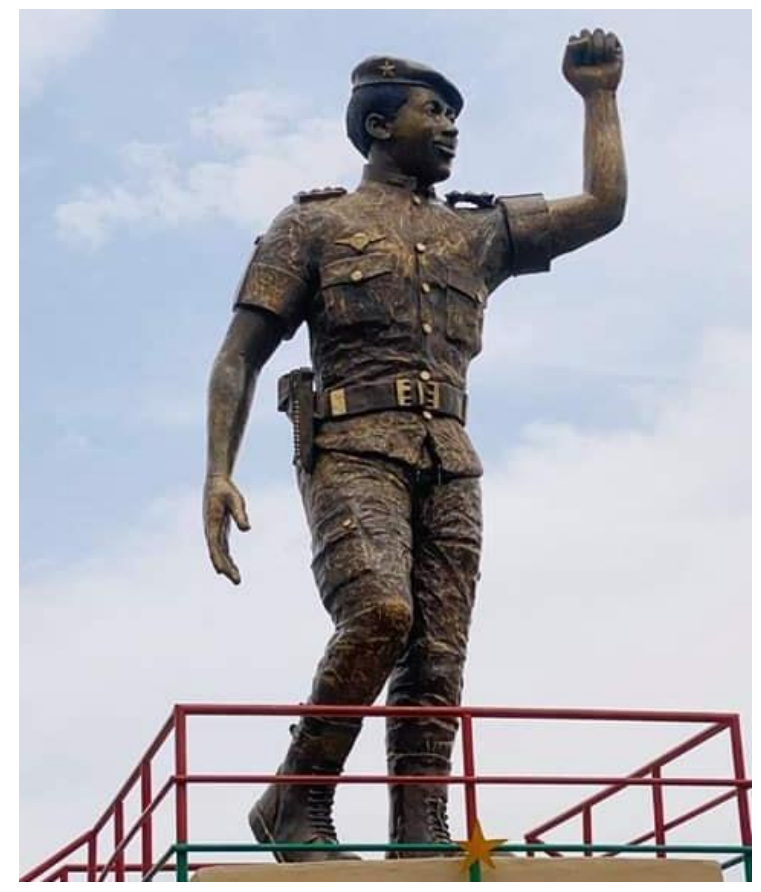

Plate 11a: Capt. Thomas Sankara - Burkina Faso. Source: Twitter

Captain Thomas Sankara was the President of Burkina Faso from 1983 to 1987 . He was a charismatic socialist revolutionary who came to power in a military coup d'état in the then Republic of Upper Volta. After seizing power, aged 33, he renamed the Country 'Burkina Faso' or 'land of the upright people' and aggressively pursued a socialist-leaning social/economic agenda that included nationalizing all land and redistributing it to peasants. He also pursued other programmes that endeared him to ordinary people such as combating illiteracy, mass immunization against recurrent diseases, outlawing female resembles that of Kim Jong-Il who actually had a slight body himself. The statue has been criticized also for having a head that lacks the facial likeness of Kabila (Plate 10b). His hand is raised with a finger raised towards the sky; he is also depicted holding a small book in his left hand.

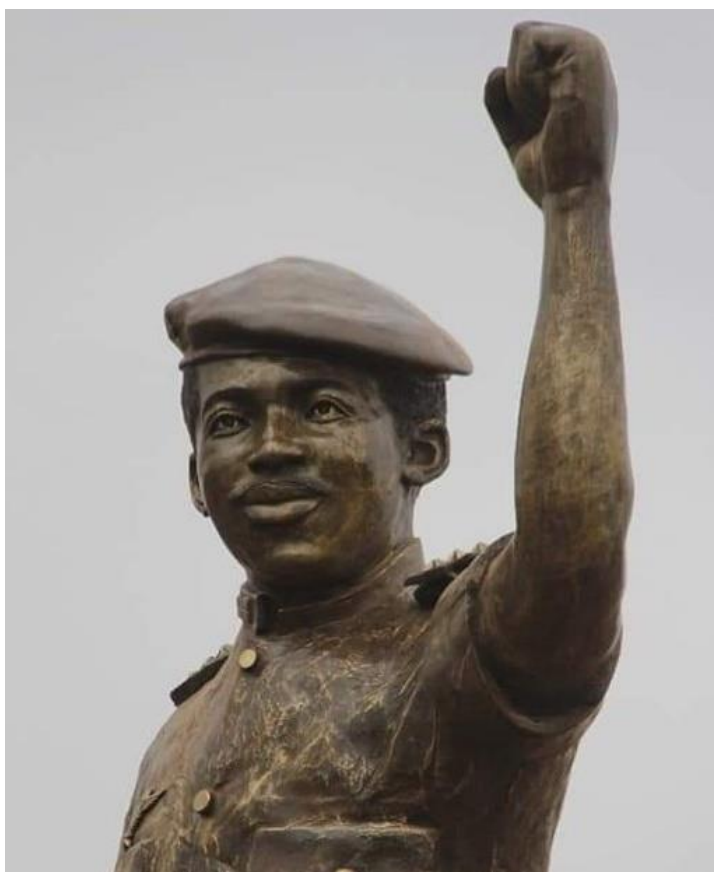

Plate 11b: President Thomas Sankara Closeup. Source: Listwand

genital mutilation and polygamy as well as forced marriages. He was staunchly antiimperialist, mounted a spirited anti-corruption campaign and sought to make his country selfsufficient. He was assassinated by a group of soldiers in another coup d'état on $15^{\text {th }}$ October 1987 aged 37. In a prophetic quote one week before his death, Sankara said 'While revolutionaries as individuals can be murdered, you cannot kill ideas' (Bonkoungou, 2007). His legacy is summed up by Smith (2014) who observes that 'African leaders have so much to learn from Sankara about humility and public service.' 
Sankara's five-metre statue (Plate 11a) stands at the site of his assassination in Ouagadougou, the capital of Burkina Faso. Done many years after his death, the statue depicts him as a heroic young army officer in military fatigues with the salute of the revolution that he was so associated with. This paper contends that the face of the subject (Plate 11b) still does not fully capture his absolute physical likeness since
Sankara had a slightly elongated face. It is, however, deemed to be an improvement upon the previous version that was rejected after people complained that it did not resemble the revolutionary African icon. This underscores the necessity that statues must, as much as possible, bear the likeness of the subject, both in body posture and face, in order to carry commemorative value

\section{Gnassigbe Eyadema}

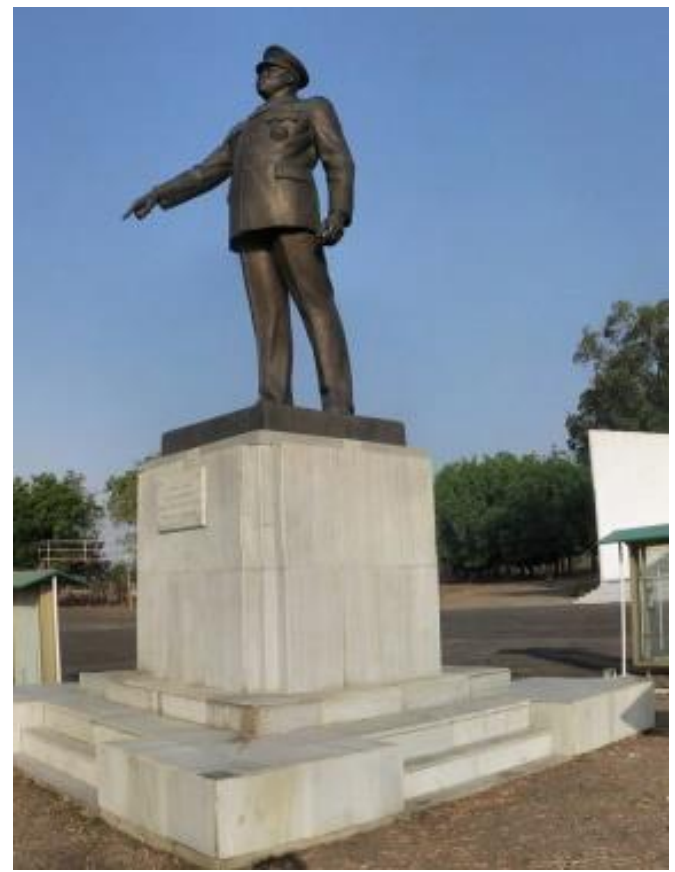

Plate 13a: Gen. Gnassingbe Eyadema Source: Togofirst.com

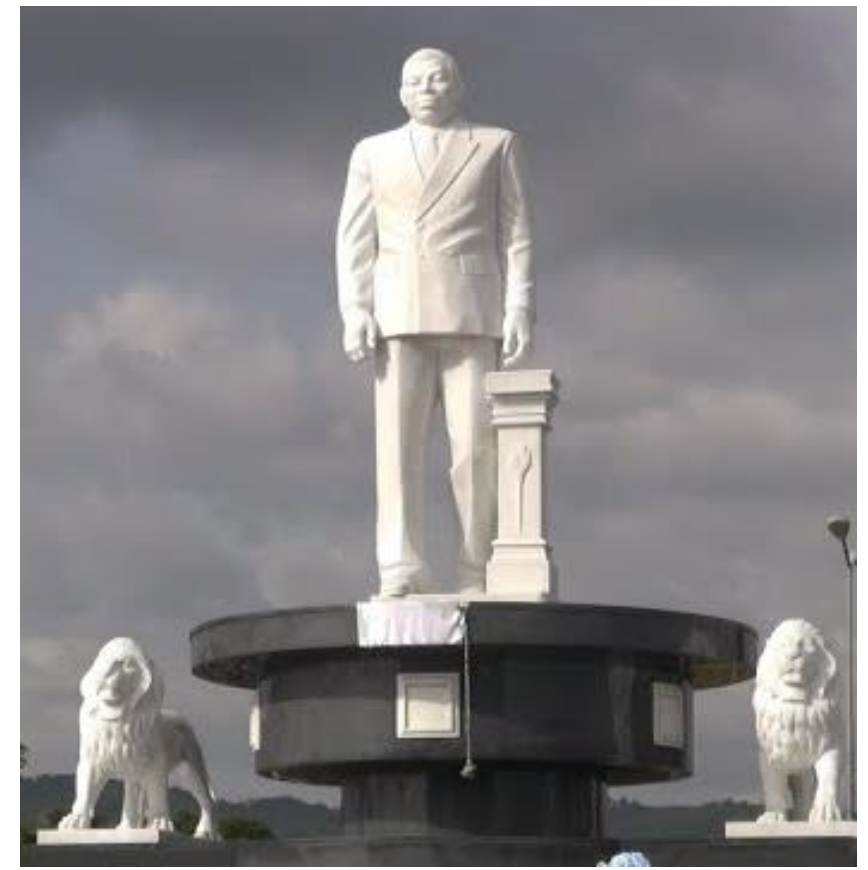

Plate 13b: President Gnassingbe Eyadema - Togo Source: youtube.com
Gnassingbe Eyadema was a Togolese military leader and politician who was the President of Togo from 1967 to 2005 making him Africa's longest-serving Head of State at the time. He also held the post of Defence Minister for the same period of time. He came to power through a military coup that ousted President Nicolas Grunitzky. He founded the Rally of the Togolese People (RTP) in 1970 making it the only legal political party in Togo until the introduction of multiparty elections in 1993 . He won multiple re-elections most of which were uncontested. He served as the Chairman of the Organization of African Unity between 2000 and 2001. He had the country's constitution changed to remove the term limit for the president ensuring his prolonged hold of power. His rule was seen as autocratic and intolerant of any form of dissent. He also encouraged an eccentric personality cult that included the belief that he possessed supernatural powers. He died in office on $5^{\text {th }}$ February, 2005.

The statue of Gen. Eyadema (Plate 13a) was erected in commemoration of the 
Presidential plane crash in January 1974 in which he claimed to have been the sole survivor. Standing near the crash site near the village of Sarakawa in northern Togo, it depicts him in military uniform in a gallant, heroic, almost defiant pose. This is meant to illustrate that he possessed supernatural strength or mystical powers that enabled him to survive such a deadly incident. Another statue made of marble (Plate 13b) was inaugurated on July 9, 2016, in the city of Kara. The statue, which is part of a larger architectural square depicts the late leader flanked by two lions.

\section{Omar Bongo}

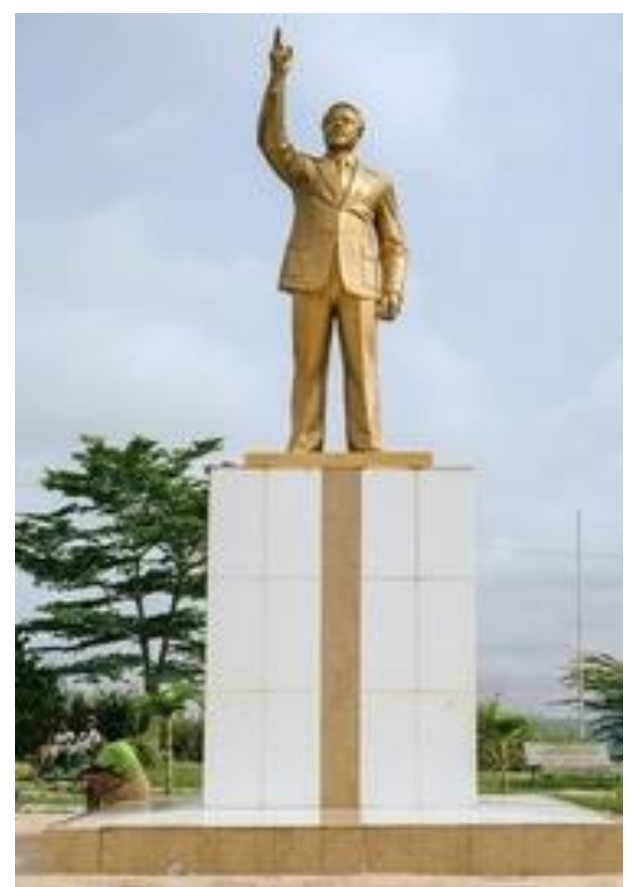

Plate 14a: President Omar Bongo Source: Chelsea 98.com

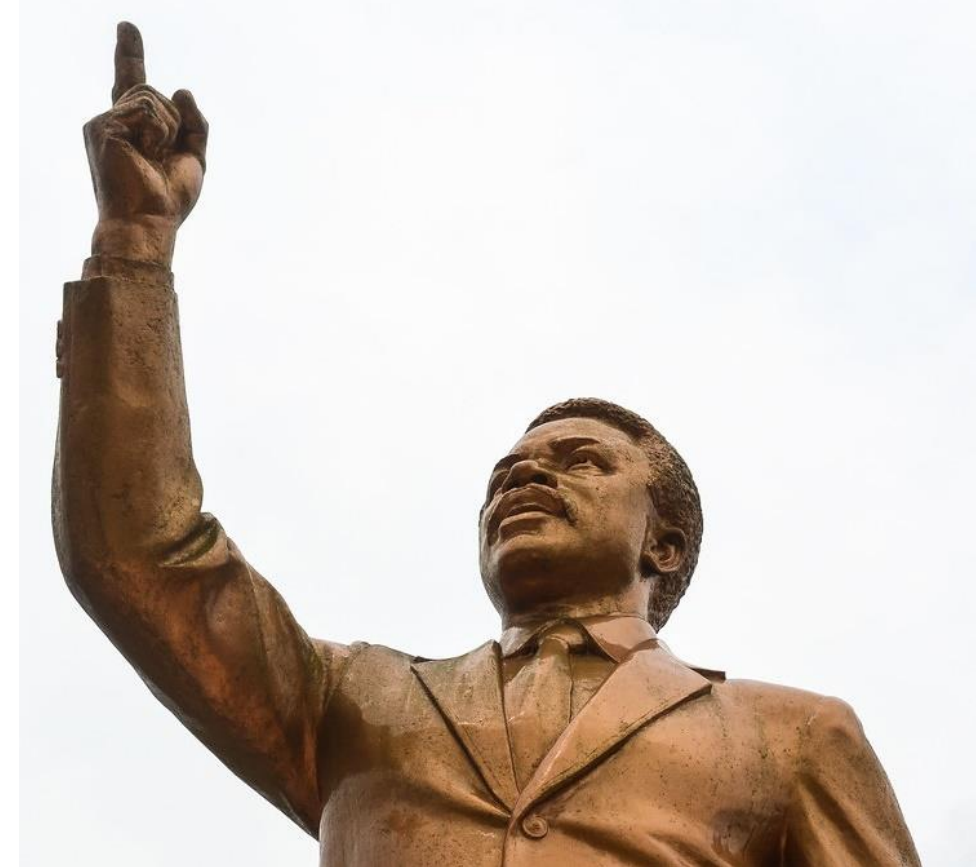

Plate 14b: President Omar Bongo - Gabon, Closeup Source: Freewheely.com
Omar Bongo Ondimba was a Gabonese politician and second President of the Republic of Gabon from 1967 until his death in 2009. Serving for 42 continuous years, he became one of the longest-serving African Presidents. He served as Vice-President from 1966 and subsequently ascended to the Presidency in 1967 upon the death of first President Leon M'ba. He presided over vast oil wealth and initially ruled the country through the one-party rule of the Gabonese Democratic Party (GDP). Through political skill and shrewdness, he overcame stiff opposition during the multiparty politics that was sweeping across the continent in the early 1990s. He won subsequent elections, extending his rule until his death. Despite the country's oil wealth, he was accused of not doing enough to lift the standards of the ordinary Gabonese people. He died in office on $8^{\text {th }}$ June, 2009 aged 73 and was buried in his hometown of Franceville.

The golden statue of President Omar Bongo Ondimba (Plate 14a) stands in Franceville, Gabon, his burial site. Mounted on a high plinth, it depicts him raising his hand in a one-finger salute with his face looking up into the sky. This kind of pose is common and is meant to provide a futuristic sense of hope and direction. 


\section{Joshua Nkomo and Joseph Kasa-Vubu}

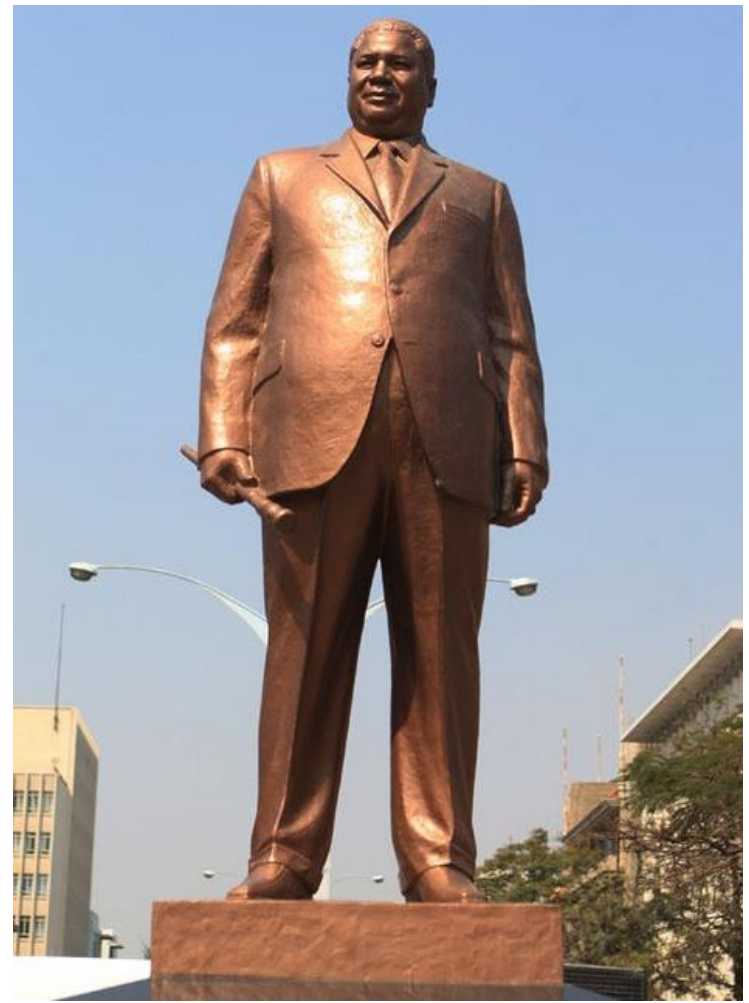

Plate 15: Joshua Nomo - Zimbabwe

Source: allAfrica.com

Joshua Nkomo was a Zimbabwean revolutionary leader and independence hero who served as Vice-President of the Country from 1990 to 1999. A revered political figure, he fought the country's liberation war against Ian Smith's white minority rule in the then Rhodesia, alongside Robert Mugabe. He and President Mugabe, however, had a strained relationship in the later years after independence and Nkomo was believed not to have subscribed to the direction the country was taking by the time of this death on $1^{\text {st }}$ July, 1999 aged 82 .

The statue of Nkomo (Plate 15), one of a pair, was erected in Bulawayo in 2013 ironically in the same spot where the one of Cecil Rhodes once stood. But the statue was earlier in 2010 heavily criticised as not bearing the likeness of Nkomo; the head was

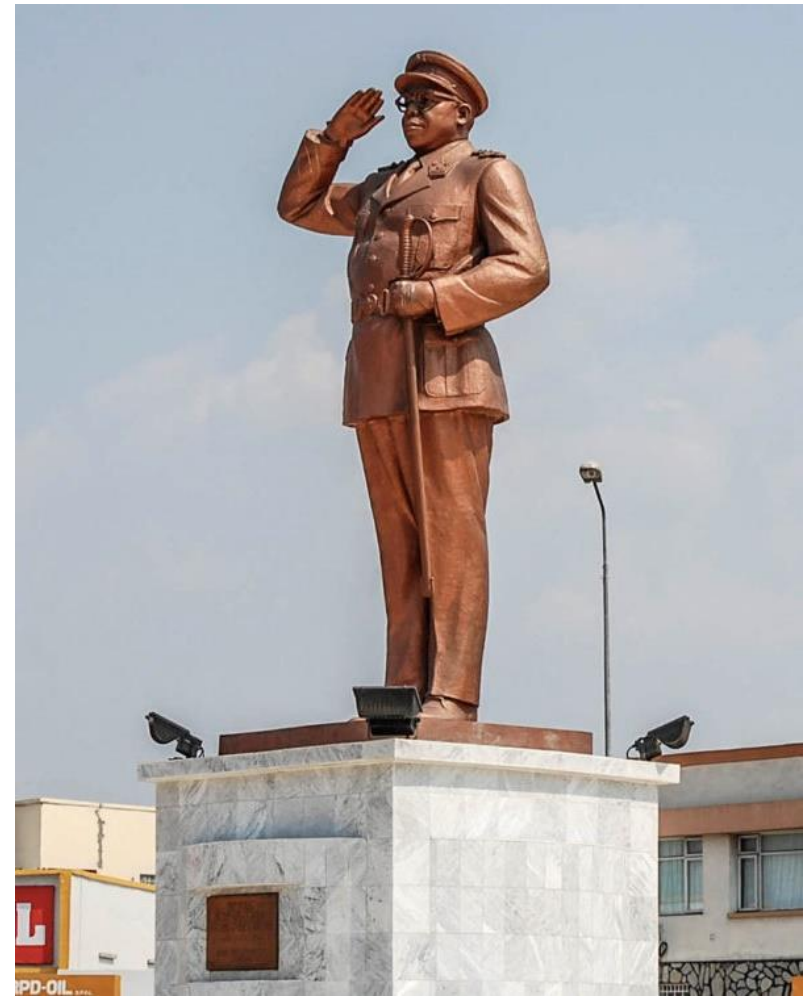

Plate 16: President Joseph Kasa-Vubu - DRC Source: Congo in Conversation

perceived to be too small for the bulky frame and was subsequently dismantled before being re-erected in 2013. It depicts him holding his hand baton which is an African symbol of authority and leadership. The statue initially created some controversy about its North Korean origin since the North Koreans also trained the infamous fifth brigade, the infantry brigade of the Zimbabwean military that was responsible for the killing of thousands of Nkomo's own tribesmen, the Ndebele, during a crackdown on dissent in Matabeleland in the 1980s. So it seemed a bitter irony that the North Koreans should be the same ones to create Nkomo's statue. The opposition to the statues was therefore both aesthetic and ethnopolitical 
Joseph Kasa-Vubu was the first President of the Republic of the Congo (now the Democratic Republic of the Congo, or DRC) from 1960 to 1965 when he was ousted by Maj. Gen. Joseph Mobutu. Although he was a moderate whose government was perceived as weak, he is revered for his role in the independence movement of the Congo. He died on $24^{\text {th }}$ March, 1969 aged around $54 . \mathrm{He}$ was instituted and recognized as a National
Hero of the Democratic Republic of Congo in June 2020.
His 5.45 metre high, 5-ton North Korean made statue (Plate 16) was unveiled in June 2010. The statue depicts the subject dressed in military uniform and bearing a dignified military poise complete with a salute and a general officer's sword. It is located in Kimpwanza square in the town of Kasavubu.

\section{Leopold Senghor}

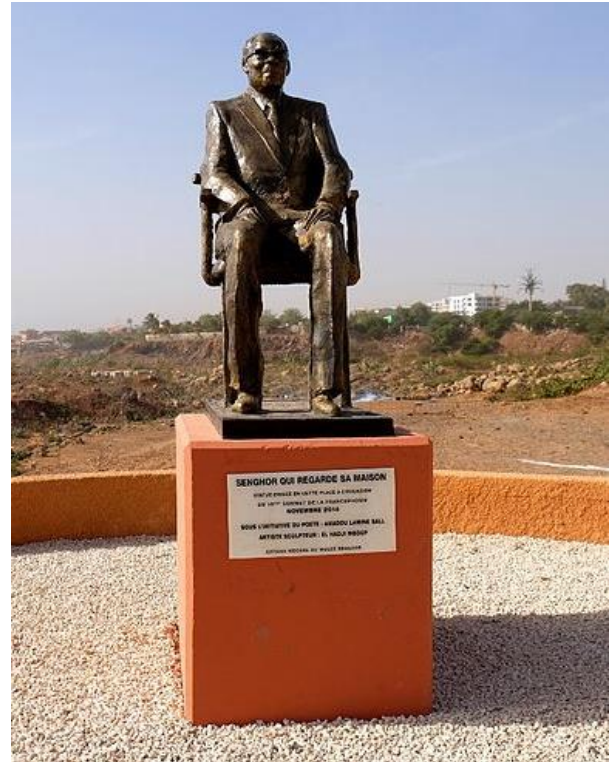

Plate 17a: Leopold Sedar Senghor Source: Face to Face Africa

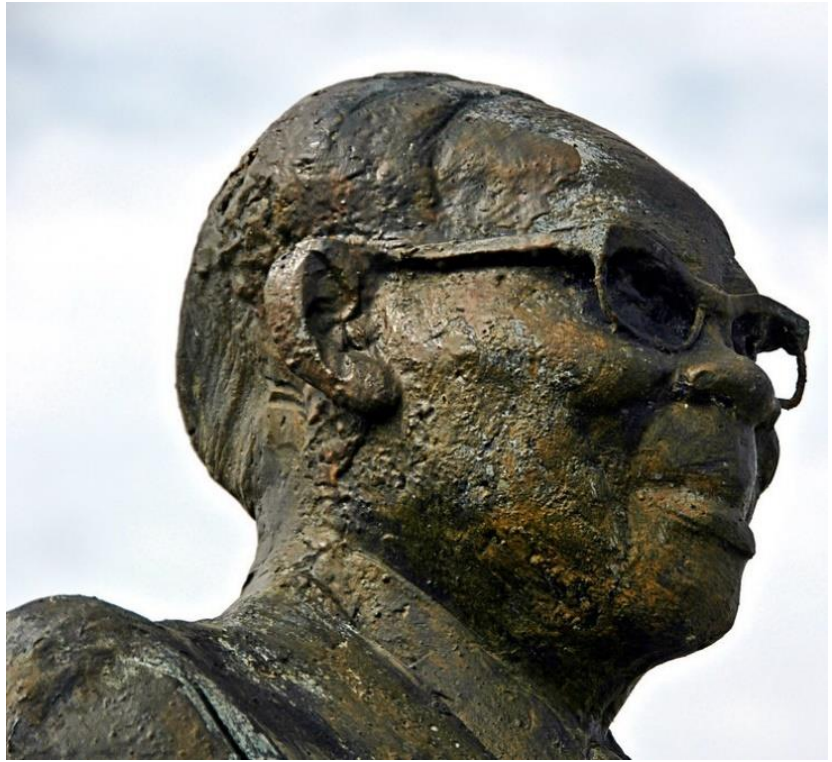

Plate 17b: President Leopold Sedar Senghor - Senegal Source: Face to Face Africa
Leopold Sedar Senghor was the $1^{\text {st }}$ President of the Republic of Senegal from 1960 to 1980. Highly educated, a poet and cultural theorist, he was regarded as one of African top intellectuals of the $20^{\text {th }}$ Century and was the first black African to join the elite French literary institute, the Academie Francaise $\mathrm{He}$ also wrote the national anthem of Senegal and was the founder of the Senegalese Democratic Bloc party. Upon independence from France, Senghor avoided the Marxist ideology which was then popular among emerging independent African Nations and instead pursued a socialist ideology but maintained close ties with France. He was a founder and chief proponent of the concept of
'Negritude', defined as the literary and artistic expression of the black African experience. He was also a keen advocate for federalism in the newly independent African countries and served as a minister in the French cabinet before his country's independence. He was credited with initiating multi-partyism in Senegal within his framework of political liberalism. He also established a free press and a strong education system. After 20 years at the helm, in a milestone act, he retired gracefully in 1980 just before the end of his fifth term paving the way for Prime Minister Abdou Diouf to succeed him as President. He died in France on $20^{\text {th }}$ December, 2001 aged 95. 
His bronze statue (Plate 17a) located at his old residence in Dakar, Senegal, stands 2.1 metres tall. He is depicted sitting on a chair on top of a one-metre-high plinth. It was constructed in 2014 in honour of his memory and work.

\section{Kamuzu Banda}

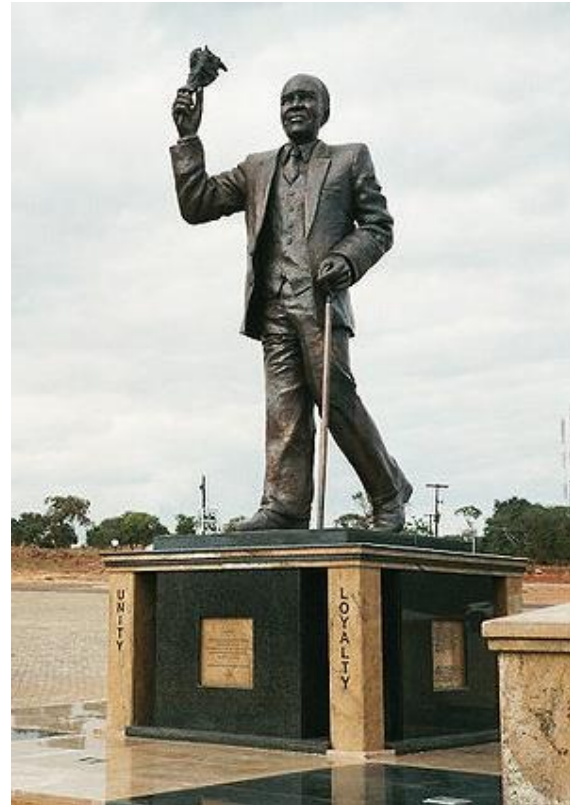

Plate 18a: Kamuzu Banda Source: Wikimedia Commons

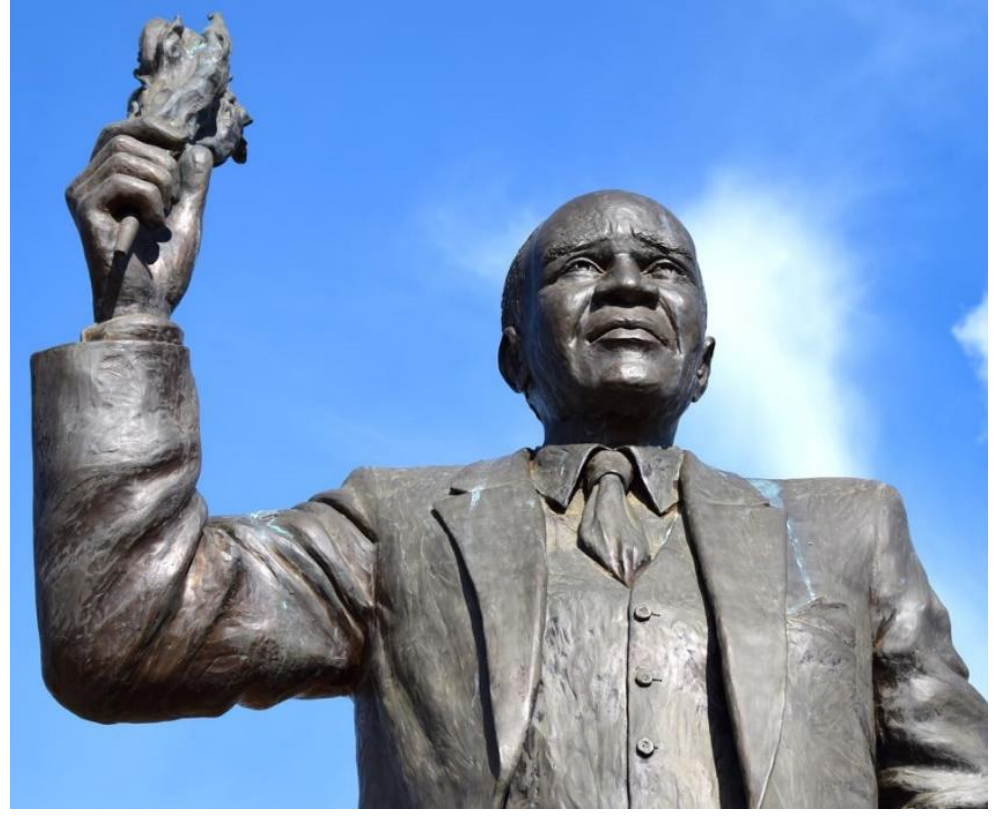

Plate 18b: President Hastings Kamuzu Banda - Malawi Source: World-adventurer.com
Kamuzu Banda was the first Prime minister of Malawi from 1964 to 1966 . He also became the first President of the country after Malawi became a Republic in 1966 and governed until 1994 when he lost in the first multi-party elections. He established the Malawi Congress Party (MCP) and subsequently declared Malawi a one-party state of which he became the President for life. In 1971 he became Malawi's President for Life and encouraged the build-up of a cult of personality. He built the country's infrastructure and improved education. He also founded the Kamuzu Academy, a prestigious institution that had the aim of producing an elite cohort of highly educated and cultured children. Banda was, however, also accused of gross human rights violations. His regime was viewed as increasingly autocratic and he gained notoriety throughout the continent for his sustained diplomatic relations with the Apartheid regime in South Africa. He was defeated by President Bakili Muluzi in the 1994 elections and graciously accepted to leave power. He died in South Africa on $25^{\text {th }}$ November, 2007 aged 99.

The statue of Kamuzu Banda which was unveiled in May 2009 (Plate 18a), it was the first to be erected at the National Memorial Park in Lilongwe, Malawi. Sculpted by Doyle Art Foundry of South Africa, the bronze statue stands on a medium-sized plinth and depicts him holding his famous flywhisk and walking stick. The statue was welcomed by a segment of Malawians including those in government but dismissed by critics who cited Kamuzu Banda's dictatorial atrocities. In view of this, Kasalika (2019) quotes the sentiments of Prof. Chijere Chirwa who in 2018 observed, in reference to the Banda statue, that "there is need for the country to develop clear 
guidelines on who deserves to be honoured rather than leave it open." Further, according to Chirwa "honouring people should be done in an open manner and probably with consultation." (Kasalika,

\section{Samuel Nujoma}

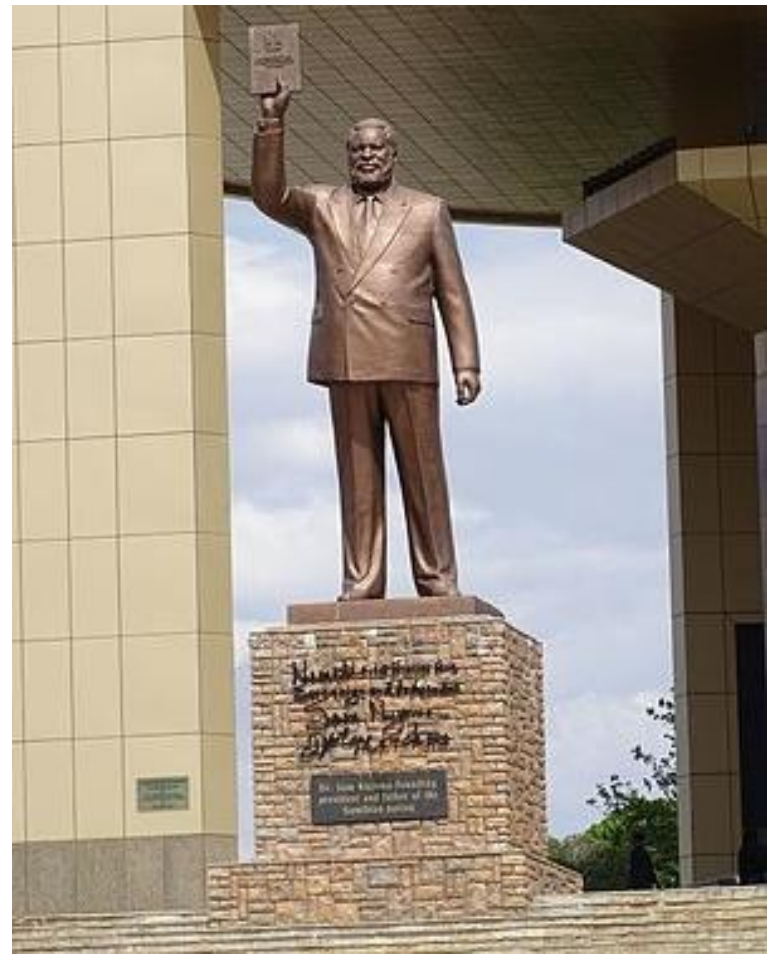

Plate 19a: President Sam Nujoma -Namibia Source: Wikiwand

Samuel Nujoma is a Namibian freedom fighter, independence hero and politician who became the first President of the Republic of Namibia and served for three consecutive terms from 1990 to 2005. He was also a founding member and first President of SWAPO (South West African People's Organizatiom) in 1960. President Nujoma also established the Military wing of his party, the People's Liberation Army of Namibia (PLAN) in 1962 and went on to launch a guerrilla war against the South African Apartheid regime. He led the Namibian War of Independence which raged on for 24 years from 1966 to 1989 and culminated in Namibia's Independence in 1990. Nujoma retired as President of Namibia at the end of his third term in 2005 and later retired as President of
2019). The Катиzu Banda statue (close-up, Plate 18b) was also critisized for not bearing the likeness of the late President and seems to have a problem with its posture.

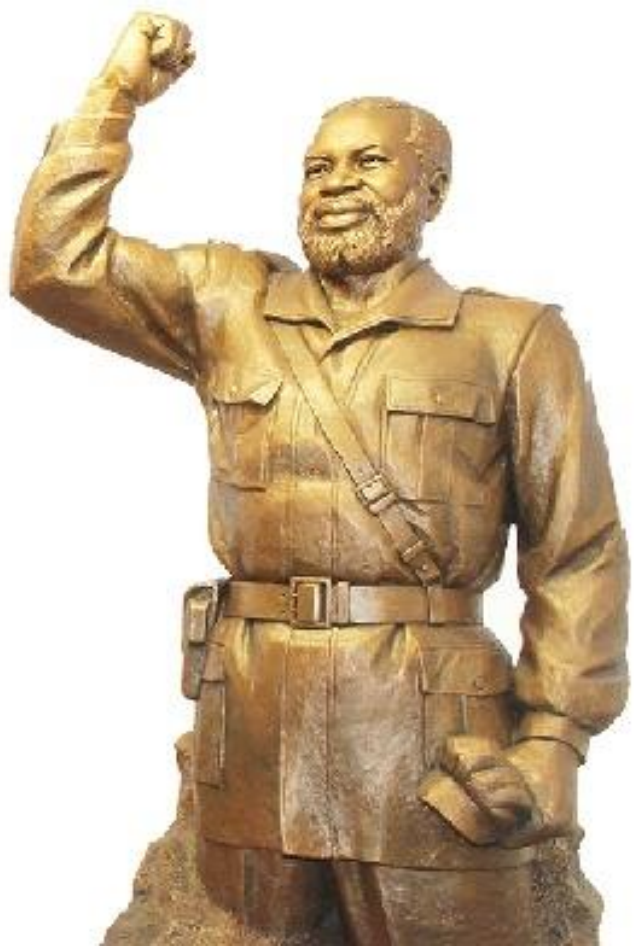

Plate 19b: Dr. Nujoma - close up of another statue. Source: The Namibian

SWAPO in 2007. He received the Lenin Peace Prize, Gandhi Peace Prize and Ho Chi Ming Peace Prize as well as many honorary degrees in recognition of his leadership. He was born in 1929.

A number of statues have been erected in honour of founding President Sam Nujoma. One of the more prominent statues (Plate 19a) stands in front of the Independence Memorial Museum in Windhoek, the Capital of Namibia. The $130 \mathrm{ft}$ gigantic statue stands on the site of the Reiterdenkmal equestrian statue, which was viewed as a symbol of colonial domination. In this North Korean made bronze statue, Nujoma is dressed in a formal business suit and is captured holding 
a copy of the Country's constitution. In the other statue plate (19b) he is depicted in military attire giving the victory clenched fist salute and holding his cap in his other hand. Another statue erected at Omugulu-
Gwoombashe (not featured here) depicts him holding a machine gun high in the air as a symbol of the armed struggle for Namibia's Independence.

\section{Bingu wa Mutharika}

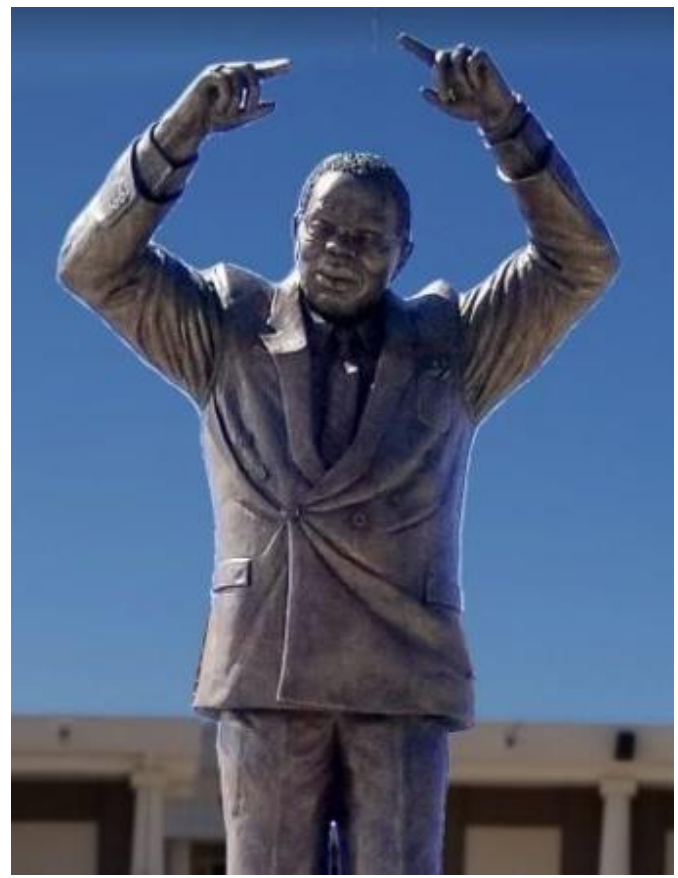

Plate 20a: Bingu wa Mutharika Malawi. Source: Malawi Nyasa times

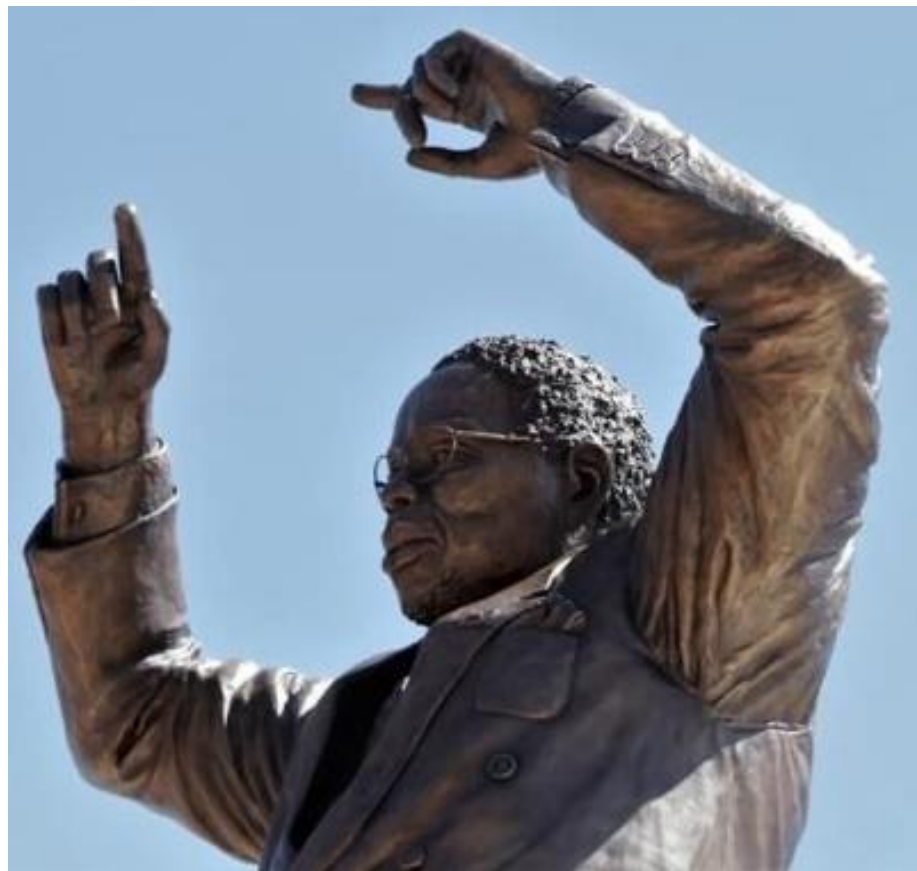

late 20b: President Bingu wa Mutharika - close up Source: Malawi Nyasa times
Bingu wa Mutharika was a Malawian politician who was the third President of the Republic of Malawi from 2004 to 2012. He founded the Democratic Progressive Party in 2005 on whose ticket he won his second term in 2009. He also served as Chairman of the African Union between 2010 and 2011. An economist with high academic credentials, some of his main areas of success included food security and agricultural production that significantly reduced levels of poverty, economic reform, legal reform and anti-corruption measures. He also paid attention to education, rural development and youth development through his Malawi Development Strategy of 20062011. He was, however, accused of highhandedness and intolerance of dissent and aspects of abuse of human rights were witnessed during his Presidency. He died in office on 5th April, 2012 aged 78.

The bronze statue of President Bingu wa Mutharika (Plate 20a) was unveiled at Parliament Buildings in Lilongwe, Malawi in April 2019. It depicts him with his signature gesture that denotes the phrase 'let the work of my hands speak for me'. However, there was widespread criticism that the statue does not bear a facial likeness to the late leader and some comments went as far as saying that he was literally unrecognizable. Writing about the statue at the time, a Nyasa Times reporter (2019) noted that, "a storm has since erupted over the likeness of the statue with many airing 
views that the bronze (statue) was not a fair reflection of the Country's former leader." However, there were differing opinions after the unveiling of the statue, 'After the unveiling of the statue by President Arthur Peter Mutharika in Lilongwe on Friday, many critics said the clear picture on the

\section{Haile Sellassie}

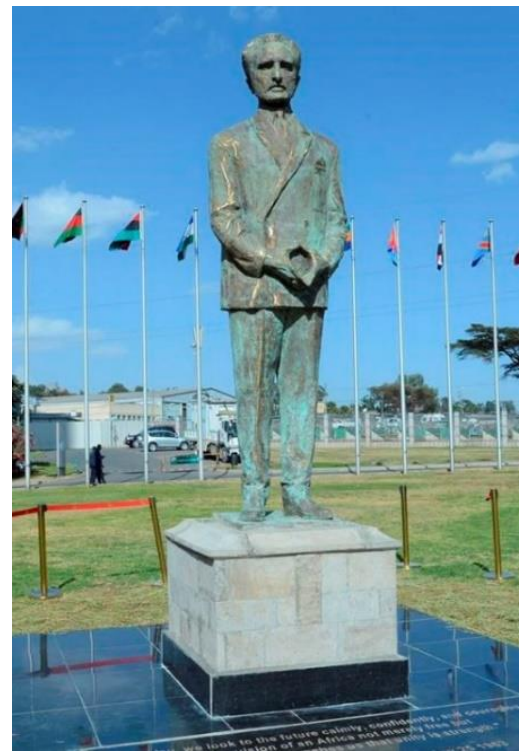

Plate 21a: Emperor Haile Sellassie Source: Quartz

Haile Sellassie was Emperor of Ethiopia from 1930 to 1974 and was a member of the Solomonic dynasty. A charismatic but aloof figure, he led a failed military effort to defend Ethiopia from the Italian invasion which culminated in his exile during the Italian occupation between 1936 and 1941. He returned to Ethiopia in 1941 after the defeat of the Italian occupying forces with the help of British forces and their commonwealth allies. He remained a trusted ally of the west but also endeared himself to the African course by pursuing a firm policy of decolonization in Africa. However, his rule was marred by accusations of human rights abuse and a series of droughts that engulfed Ethiopia and caused great suffering. His rule was also engaged in a prolonged war with Eritrea which he declared a province of Ethiopia. The Eritrean War of statue now looks a fair reflection of the country's former leader." And further that "Bingu's statue is clearly depicting him with his signature gesture to the country that "let the works of my hands speak for me." (Nkolokosa, 2019)

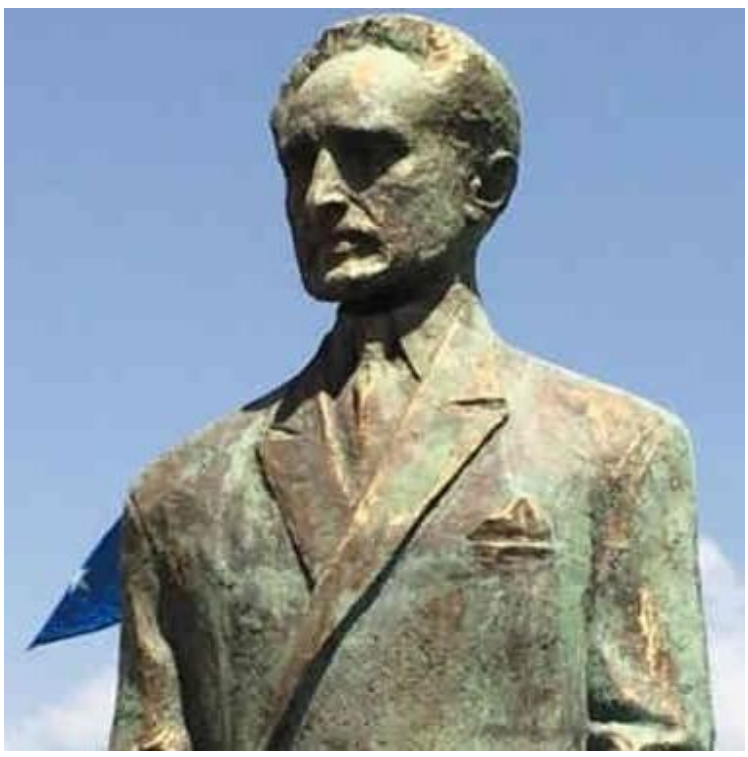

Plate 21b: - Emperor Haile Sellassie - close up. Source: Eritrea-Focus

Independence raged on for thirty years outlasting his own rule. He was instrumental in the founding of the Organization of African Unity which established its headquarters in Addis Ababa and who's first sitting he presided over as the first Chairman in May 1963. He was overthrown by the Derg, a committee of Ethiopian junior military officers in September 1974 after months of domestic unrest and relentless mutinies by a restless army. He was subsequently imprisoned at the Grand palace and died under mysterious circumstances on $27^{\text {th }}$ August, 1975 aged 83. It was suspected that he was murdered by soldiers.

The statue of Haile Selassie, in Addis Ababa Ethiopia (Plate 21a and close-up, plate 21b)) was unveiled at the African Union headquarters on February 10 $0^{\text {th }}$ 2019. This 
was the first significant commemoration of the former Emperor since his overthrow in 1974 and subsequent assassination in 1975. It however attracted emotions from both his supporters, particularly the Rastafarians, who are still nostalgic about the monarchy; and his detractors who felt that he neglected the ordinary people and instead encouraged a God-like cult of personality around him. The statue itself is testimony to his own rehabilitation as an African statesman and "in recognition of his role as a champion of African freedom against colonial intervention." (Plaut, 2019)

\section{Overview and Observations}

This paper draws the following observations.

- There was recurrent observation that a significant number of statues do not meet the highest standards of likeness. The whole purpose of a commemorative statue is to capture the detailed and accurate representation of the subject both in terms of the facial appearance and the body structure.

- The statues bear a characteristic feature of a physical gesture mainly a raised arm or a pointing finger or both. This is an artistic and visual way of communicating a message often perhaps associated with the subject such as a vision, or way forward, astuteness, or providing National direction. Other statues depict the subjects holding or adorning a certain symbol of authority or dressed in certain traditional regalia or unique outfits, like military uniforms that were associated with their personal demeanour.

- Statues are erected in distant cities meaning that they are not seen by a great majority of citizens who, therefore, do not attach any meaning to them.

- Statues are often presented as mere tourist attractions for hapless tourists to gawk at and where their locations become tourist destinations not necessarily for educative or historical purposes but because they are on the tour guide's route plan.

- That many statues tend to be placed in very high plinths. This is mainly for security purposes to avoid constant tampering with the statue, defacing and to prevent any other kind of satirical mischief. Members of the public often do not appreciate that although statues are static, lifeless monoliths, they still carry the 'commemorative dignity' of their subjects by association and should be treated as such.

- The commemorative value of statues may be watered down in certain contexts by ethnicity. This means that even among those viewers who actually see the statues, they feel that that particular individual is not one of their own and hence feel no sense of commemorative association.

- That in many instances, the intended commemorative value of statues is often not aligned to the current plight of many of the citizenry culminating in the statues appearing like elitist monoliths that have no appeal to people who still struggle with daily challenges. This situation also culminates in resentment that undermines the purpose of commemoration in the first place. For instance, in reference to the North Korean made African Renaissance Monument in Dakar, Senegal, a post by Art F City (2014) notes, "Like in North Korea, the cartoon-like body shapes and hopeful, glorified message stand in contrast to the surrounding desolate landscape filled with poverty."

- The often-high cost of bronze statues seems to raise eyebrows among the general public who even though they have no objection to the notion of commemorative statues as such, feel that there remains at all times other more pressing priorities particularly when 
the amounts involved could directly address tangible identifiable problems in their midst. This has been raised in the case of many of the African statues in view of the amount of public funds used in the projects, seen against tangible, practical priorities. This is fundamentally true since consideration of expenditure on statues and monuments must be seen to be in consideration of other aspects of budgetary expenditure that directly impact upon the lives of the respective community. For example, members of the public are at times awed by a very expensive statue in circumstances where they have no running water in their midst. According to the post by Art F City (2014) commenting about the African Renaissance Monument in Dakar, Senegal, Djiby Diakhate, a sociologist at Dakar's Cheikh Anta Diop University, told the Associated Press at the time, "Senegal is going through a profound crisis. Our economy is dying. People are struggling to eat. We should be spending money helping people survive."

- That since the decision to erect statues is often a government decision or emanating from the respective authorities, there is no accompanying public participation and hence the whole principle of commemoration is not adequately internalized in the public psyche.

\section{CONCLUSION}

From the foregoing, the following conclusions can be derived:

That the African leaders featured in this paper were extremely accomplished individuals, many of the founding fathers and independence heroes of their respective Nations and many of them outstanding politicians and genuinely revered individuals. This paper does not, however, delve into their individual legacies as such, but it can be concluded that even by their formative achievements alone, their commemoration can be considered justifiable to a greater degree.

The application of the concept of the four $W$ 's who, why and when has been and remains very controversial even before we get to decide which means of commemoration fit the respective individual. It is important, through an identified criterion, to decide who deserves commemoration. This must be accompanied by a widely acceptable citation that underscores why that individual qualifies and deserves to be commemorated. This may include reasons why, on the other hand, that individual may not qualify. In some instances, a historical timelapse helps to determine the above two; some individuals are seen in a bad light at the time of leaving power or at the time of their demise but are ultimately rehabilitated after a review of their tenure or in the wake of new circumstantial evidence or political and other events. Hence, the notion of when or the 'timing' of commemoration becomes critically important too. Good examples of this occurrence are in the case of President Nkrumah of Ghana, Patrice Lumumba of the DRC and Capt. Thomas Sankara of BurkinaFaso. After the above issues have been addressed, then the matter of detail of which means of commemoration shall be applied is then focused upon; whether it shall be a statue, coins or currency, postage stamps, naming of roads or other national facilities like airports, universities or hospitals.

That the idea of commemoration through statues is well articulated in African countries and a significant number of them have proceeded to honour and immortalize their revered political leaders, particularly the founding fathers, by way of huge statues. Some of these statues are by and large of good artistic quality in terms of materials and workmanship and are bound to withstand the test of time. Some have not weathered the storm so well. 
That some statues, though still standing in place, still appear to spur controversy mainly because of lingering opposing political positions that have divided the respective countries for a long period of time and are still constantly inflamed by political rhetoric. This scenario constantly threatens the commemorative essence of the statues themselves and renders them contradictions of public memory. Not all political leaders need to be commemorated through statues. Indeed, some former leaders have declined or discouraged the culture of unnecessary adulation through statues.

In the context of African political thinking, there are many perspectives through which commemoration is viewed which often complicate the entire concept of commemoration rendering it in some cases, retrospectively meaningless. It is widely understood by humanity at large that ideally, a statue should commemorate an individual who draws adequate or even indisputable consensus on his or her individual selflessness and sacrifice for their country; and whose personal conduct, individual dignity and acts of humanity towards his or her fellow human beings are proven, documented and beyond reproach. Since this paper focuses on political leaders, the commemorative benchmark should be based on concrete political achievements, verified and accepted as truthful by a consensus of relevant related bodies. However, it is notable that other factors come to play such as ideology, ethnicity, regionalism and even personal acrimony that blur the wider picture of consensus based on pragmatism, objectivity and concreteness of achievement.

That statues when well executed, serve as ideal commemorative tools from both artistic and historical perspectives, even in circumstances where the whole country may not necessarily totally subscribe to the particular commemoration.
That the degree of physical likeness in a statue is critical for public appreciation, association and perception. This paper contends that in terms of commemoration, members of the public (or the audience) are divided into two main categories. The first category comprises those who may have known or encountered the real-life physical appearance of the subject of commemoration and are better placed to appreciate his or her sculptural likeness based on recollection and the fact that they can judge the accuracy of the likeness for themselves. This appreciation culminates in varying degrees of nostalgia for those amongst them who subscribed to the leadership of the subject and hence honour his or her memory. In other instances, others may appreciate the likeness but not necessarily develop any nostalgia because they did not subscribe to the leadership, policies or actions of the subject at the height of their power. It must be noted that this category, however, decreases rapidly with the progression of years and is always, therefore, a continuously diminishing group of citizenry who eventually vacate the scene. For example, Ghanaians who were old enough to have encountered President Kwame Nkrumah during his height of power between 1957 and 1966 are very elderly now or have already passed on. They probably are not in a position to view or appreciate any statues now. The second category comprises those people who did not encounter the subject in real life and hence bear no reference mental image. They subsequently only refer to different types of published historical images. Their response is, therefore, mainly based on the association of likeness based on the images through which they peruse. Since they did not encounter the real-life subject and cannot, therefore, recall their physicality, personality or character, they are only able to construct a mental perception of the qualities of the subject in order to arrive at a definitive personal perspective. If a statue is able to adequately elicit this association of likeness that culminates in a positive perception 
of the subject, then it can be rated as a successful commemorative item.

Statues are made for posterity and the level of physical likeness in execution is particularly important in rendering the statue historically appropriate. Any statue that bears questionable physical likeness or resemblance to the subject, either on the face or body posture serves no commemorative purpose and can be misleading.

Unlike other subjective sculptures where the audience may not be qualified to make artistic evaluation of intellectual judgment, statues bear likeness that they can address and engage with. They can relate with and decide whether they agree with the rendition of the face, body posture, attire or other personal symbols associated with the subject.

Statues as entities are themselves not educative; they are actually very static and impersonal monoliths; one does not stand in front of a statue and become educated. Statues are instead catalysts to inquiry; one is inspired enough to ask relevant questions, the first being who really that individual was; what he or she accomplished and what the concrete personal legacy is. Some of the statues being brought down in recent times are as a result of this kind of inquiry where the answers to these questions led to negative conclusions.

Statues bear a visual presence mainly because of their size and posture. It is not certain, however, that this visual dominance translates to an uptake of recognition or appreciation of the achievements of the subject or even the identity of the subject. It can be concluded that there exist other factors that prevent people from adequately internalizing the essence of statues and by extension, whom or what they represent. This phenomenon indicates that statues can be physically visible but contextually absent. Moran (2007) notes that "Despite their commemorative rhetoric, memorials and monuments have a relatively short life-span after which their overt meaning and relevance diminishes and they become anonymous landmarks or ornamentation."

Some of these factors include the passage of time from the point of death, that diminishes the allure of adulation and subsequently of the subject's stature; the changing generational landscape where younger people are more preoccupied with and attracted by contemporary events rather than what they consider by-gone eras; lack of adequate historical sensitization about the role played by key historical figures, such as their political contribution no longer resonates with people and hence ultimately fades away; lack of a culture of reading among the citizenry and particularly among the youth which means that they are not adequately informed about both current affairs and historical perspectives; lack of structured National commemoration; effects of ethnicity that drives the feeling that a certain individual or individuals do not belong and hence do not deserve to be commemorated. This implies, therefore, that statues and other monuments have to be subjected to reinterpretation at certain intervals in order to inject new impetus for renewed political meaning and hence create a sense of relevance in line with contemporary times. In this regard, Lentz (2017) observes that "monuments do not speak for themselves but depend on the cocreation of meaning through a variety of other media, including further iconographic representations as well as performances, such as wreath-laying ceremonies or re-enactments of historical moments, accompanied by speeches and newspapers reports that offer competing readings of the statue and the hero it portrays." In his argument that statues need constant engagement, Lentz further posits that "although monuments are apparently built for eternity, they remain vulnerable, and are open for continuous redefinitions and reappropriations." In reference to how Nkrumah's statue located at the Nkrumah memorial park, has been made to come alive at 
certain designated times, Lentz singles out the theatrical re-enactment of Nkrumah's midnight declaration of independence and notes that "the ceremony has further contributed to enshrining the gleaming gold Nkrumah statue firmly as the dominant icon of Ghana's independence."

It is observed that all the statues examined in this paper fall under the category that underscore avowedly euphoric or heroic undertones that are inspired by a continuation of political adulation of the subjects in death as it existed in life. Some of the statues are placed in environments that depict a celebratory mode.

Hard questions still linger about the holistic legacies of some of the individuals featured in commemoration. Although this paper does not dwell or even delve into this controversy, the questions are persistent and loud. It is argued that while some of these leaders were certainly useful and played a pivotal role at certain points in the history of their countries, they also played an equally significant part in the impoverishment of the same countries by the decisions and ideologies they pursued. Others are perceived to have gone further and actively participated in the enrichment of themselves, their families and cronies at the expense of their countries economic development and general wellbeing of their people; to use a more blunt term, the 'plunder' of their countries. Some were suspected to have abetted some of the atrocities that occurred under their watch and others were accused of pursuing dictatorships that were self-preserving but ironically completely contrary to the spirit of the free democratic states that they themselves envisaged. There are perhaps clear historical reasons why this flourished, particularly the complexity of post-colonial dispensations, geopolitical alignments during the cold war, the scramble for mineral and other resources in the continent and the quest for self-perpetuation in the case of many of these leaders.

\section{RECOMMENDATIONS}

\section{Physical Likeness}

Contrary to what some people have asserted, statues must, in essence, bear the physical likeness of the subject that is accurate and indisputable. The facial likeness must be accurate; body posture, proportions and description of the body must be a correct representation of the subject of commemoration even when the statue has been magnified. As earlier observed in the conclusion, any statue that bears questionable physical likeness or resemblance of the subject, either in facial execution or construction of body posture serves no commemorative purpose. Such a statue upon recommendation from a consortium of professional sculptors and other art scholars should be brought down to avoid subsequent years of visual misrepresentation that is actually misleading to the public. To avoid a situation that leads to the above scenario, statues should procedurally be subjected to a panel of peer reviewers who are qualified to vet and pass the final product. This, of course, depends on the level of professional expertise applied in the first place as well as the style and technique used to create the respective statues. Some modern hyperrealistic techniques used in cast statues are very accurate and eliminate to a large extent the likelihood of facial distortions or lack of likeness. The real problem starts at the modelling stage. Indeed, some of the criticism that has been levelled against statues done outside Africa, for instance, the ones done in North Korea is that the statues do not depict African features of the subjects; the artisans do not understand African features as an integral basis of constructing the statues.

\section{Size of Statues}

Some statues are too huge that they are intimidating rather than attractive. The placement of statues should take into account the holistic spatialization of public spaces 
particularly the appropriate ratio of the size of the proposed statue to available space. There is a difference between a large impersonal monolith and an interactive statue. Statues should also not be too small that they are consumed and overwhelmed by their surrounding space making them not only commemoratively redundant but spatially insignificant.

\section{Location of Statues}

A great deal of thought needs to be put on the location of a statue. This paper recommends that statues should be placed in designated areas, preferably a park where people can alight and purposely walk there and take time to interact with the statue and other memorabilia. One superb example is the Kwame Nkrumah memorial park in Accra, Ghana, which includes the burial mausoleum, the statue itself, a water pond and a host of accompanying statues of traditional Asante elephant ivory tusk blowers that create an 'eternal' celebratory and triumphal allure through the illusion of blaring trumpets and dance. Another appropriate space is a National memorial square in cases where there are a number of statues placed together where members of the public can visit on an educative tour. Another alternative is the individual memorial location such as a Presidential library and burial site of the subject of commemoration, or a location that bears special significance in the memory of the subject. Some statues are placed right in the middle of cities with high traffic, on intersections or roundabouts, making them a distraction to motorists and pedestrians alike who are too preoccupied with the hustle and bustle of life to take adequate interest in the statues. The statues are therefore redundant, misplaced and distracting.

\section{Funding of Statues}

Private funding for statues should be sought as much as possible to keep the use of public funding at a minimum. Ethical concerns have, however, been raised about private funding mainly that anybody then can be commemorated as long as a desired statue can be paid for. This can be addressed through the formulation and enforcement of legal criteria for public commemoration enforced through a legal approving body.

\section{Approvals and Public Participation}

Statues and other public art are approved differently in various countries. In some situations, statues of certain prominent public figures are approved by relevant public bodies such as parliament, regional or county assemblies, or committees that act on their behalf. This is in view of public expenditure and historical implications to National unity and public perceptions. This mode of approval provides due interrogation of the purpose and nature of such important public art projects. In other countries such statues are left to the discretion of relevant Government ministries, ideally, the ministry of the Arts and Culture or ministry of National Heritage (or whatever name the relevant ministry bears). What often lacks is an authorized professional body that puts in place all necessary controls and ethical measures including ensuring that even after approvals are granted for the commencement of the work, the statue ultimately meets artistic standards of likeness and other aesthetical thresholds for purposes of public display. In most cases, the lack of such bodies has culminated in statues being put on public display that nobody has seen before, that have not received any form of vetting or review. These statues are also often supervised on behalf of the client and approved by officials who are neither qualified nor competent to do so. A significant number of statues featured in this paper have been received with public dismay particularly on the matter of facial likeness.

\section{Bringing Down of Statues}


Some statues in Africa, some of which have stood for hundreds of years have been controversially brought down and replaced with others on exactly the same spot that the older one stood. Depending on which side of the social/political divide one subscribes to, this replacement has usually been met with either indignation or with joyful ululation. For example, the statue of Joshua Nkomo replaced that of Cecil Rhodes in Bulawayo; that of Sam Nujoma replaced the Reiterdenkmal equestrian statue which stood for 102 years.

It is, of course, understandable and justified that statues that carry a painful legacy must be brought down from prominent public places mainly because, in a new dispensation, they exist in irrelevance and hence can no longer retain their prominence. The problem, however, with bringing down such statues is the tendency to destroy them. They should not be destroyed as such, but their prominence should be deemphasized. This paper contends that statues by their nature are historical relics and history itself is not always joyful or euphoric; it has its share of pain and sorrow. The statues should indeed be relocated and mounted for public display in designated public places such as museums of political history. this is because they still carry a historical connotation even though their continued presence is incompatible with the contemporary times. By such action, public memory is therefore well directed and balanced such that people never forget; as it often said, 'lest they forget'.

The keywords to note in this argument are prominence and prominent public places. In bringing down a statue one denies it its 'individual prominence' and removing it from its place denies it the 'prominence of a public place' which is part of ensuring appropriate spatialization of public memory. It must be borne in mind that while certain current generations may still harbour the memories of certain times in history that they would rather put behind them, future generations will bear no such sentimentalities. They shall require to be presented with fundamental historical facts in order to internalize the history of their country as it unfolded. Ironically, such internalization requires amongst other things 'relics of artistic evidence'. These relics of artistic evidence, such as deposed statues, do not have to occupy prominent public places but are preserved and made available for viewing in more controlled environments where the message they portray is always disseminated in its correct context and perspective. The role of such work is to satisfy historical curiosity and to a certain extent, bring about what can be termed as 'extended generational historical closure'.

\section{Proliferation of Statues}

Too many statues of the same individual can be counter-productive to the memory of the individual. Many different statues of the same subject often arise when there is overwhelming admiration for the individual and hence the clamour for association with his or her legacy. Many statues of the same individual often culminate in different physical representations, meaning the depiction of different degrees of likeness. This causes visual confusion in public memory which is extremely detrimental to commemoration. Proliferation of statues can also occur in situations where successive administrations may want, for political or competitive reasons, to honour 'their own' crop of individuals. An authorization body should be able to bring to bear the appropriate controls not only about the standards of statues but also about their proliferation, individual essence and eventual placement.

\section{Performances around Statues}

Statues of prominent national heroes should not be left to stand alone, appearing desolate, analogically forlorn and exuding no new meaning; after all, statues alone tell no tales. 
Apart from the normal maintenance of the statues, certain planned activities or ceremonies around them together with appropriate public education and sensitization can help invest new political meaning in statues, redefine them or even rekindle degrees of nostalgia. Such ceremonies should, however, be held under contexts that consolidate national unity and purpose, not certain partisan interests.

\section{Attacks on Statues}

Attacks on statues are not unusual and are often an indicator of social/political frustrations among the sections of the public that are misdirected towards a non-responsive art form. The first such incident against a statue of an African leader perhaps occurred in Ghana after the overthrow of President Kwame Nkrumah in February 1966. His statue outside Parliament was decapitated and the back of the torso was extensively damaged. The remnants, including the separated head, are on display within the Kwame Nkrumah Memorial Park in Accra, Ghana. Angry protestors, mostly youth, set on fire the statue of Dr, Nnamdi Azikiwe, the First President of the Federal Republic of Nigeria in Onitsha, Anambra State in October, 2020. They accused him of being the cause of Nigeria's problems by advocating for a unitary State. Libya's Colonel Muammar Gadhafi's statue was destroyed at about the time he was ousted from power in October 2011. Statues are, therefore, vulnerable and that is why they should be placed in locations where they can be well protected. As observed before, adequate and continuous public sensitization of the purpose of statues is of paramount importance in order to minimize such occurrences.

\section{REFERENCES}

Art F City. (2014). Disney and Despotism: Why Governments Buy North Korean Art. Accessed on November 28, 2020 from Dallasartdealers.org, http://dallasartdealers. org/disney-and-despotism-why-

governments-buy-north-korean-art/

Becker, J. (2014). The Pursuit of Selflessness. Accessed on October 30, 2020 from Becomingminimalist.com, https://www.bec omingminimalist.com/selflessness/

Bonkoungou, M. (2007). Burkina Faso salutes "Africa's Che" Thomas Sankara. Accessed on October 14, 2020 from Reuters, https://www.reuters.com/assets/print?aid=U SL17577712

Bull, A. C. \& Clarke, D. (2020). Agonistic interventions into public commemorative art: An innovative form of counter-memorial practice? Constellations, 1-15. DOI: 10.1111/1467-8675.12484

Frank, P., \& Preble, D. (2011). Prebles' artforms (11th Ed.). Boston: Pearson/Prentice Hall. Accessed October 17, 2020, from http://creativecarellc.com/art-for -commemoration/

Henriques, G. (2016). The Content of Our Character. Accessed on October 30, 2020 from Psychologytoday.com, https://www.ps ychologytoday.com/us/blog/theory-knowle dge/201609/the-content-our-character\#

Kasalika, J. (2019). Bingu statue ready. Accessed on October 20, 2020 from mwnation.com, https://www.mwnation.com /bingus-statue-ready/

Lentz, C. (2017). Ghanaian "Monument Wars." The Contested History of the Nkrumah Statues (No. 227, pp. 551-582). Éditions de l'École des hautes études en sciences sociales. 
Levinson, S. (2018). Written in Stone: Public Monuments in Changing Societies (Twentieth Anniversary Edition). Durham and London: Duke University Press. Accessed on October 19, 2020 from https://www.dukeupress.edu/Assets/PubMat erials/978-1-4780-0280-2_601.pdf

Monfils, B. S. (1977). A multifaceted image: Kwame Nkrumah's extrinsic rhetorical strategies. Journal of Black Studies, 7(3), 313-330.

Moran, L. (2007). Commemorative Public Art' Dublin city arts office. Accessed on October 14, 2020 from dublincityartsoffice.ie, http:// www.dublincityartsoffice.ie/content/files/C ommemorative_Public_Art_by_Lisa_Mora n.pdf

Nigel's Statue Reviews. (2007). The Patrice Lumumba monument project; Nijel's "Patrice Lumumba: The Vision, The Legacy". Accessed on November 28, 2020 from Nijart.com, http://www.nijart.com/Lu mumbareviews.htm

Nkolokosa, C. (2019). Sculptor defends his Bingu statue: this is a true reflection of Malawi ex-President. Accessed on November 18, 2020 from Nyasatimes.com, https://www.nyasatimes.com/sculptordefends-his-bingu-statue-this-is-a-truereflection-of-malawi-ex-president/

Nyasa Times reporter. (2019). Bingu wa Mutharika statue at Parliament: Malawi leader set to unveil it. Accessed on November 18, 2020 from Nyasatimes, https://www.nyasatimes.com/bingu-wamutharika-statue-at-parliament-malawileader-set-to-unveil-it/
Plaut, M. (2019). Emperor Haile Selassie Statue joins list of Africa's troubled memorials. Accessed on November 16, 2020 from the conversation.com, https://theconve rsation.com/emperor-haile-selassie-statuejoins-list-of-africas-troubled-memorials111679

Robinson, G. (2020). The content of their character: King's theme across the years. Accessed on October 30, 2020 from https://www.aei.org/articles/the-content-oftheir-character-kings-theme-across-theyears/

Schlenker, B. R. (2008). Integrity and character: Implications of principled and expedient ethical ideologies. Journal of social and clinical psychology,27(10), 1078-1125. DOI: 10.1521/jscp.2008.27.10. 1078

Seda, E. (2015). Jomo Kenyatta Statue/James Butler. Accessed on November 21, 2020 from Archidatum.com, http://www.archidat um.com/projects/jomo-kenyatta-statuejames-butler/

Seretse, G. (2008). Khama's statue turns west Accessed on October 16, 2020 from Mmefi.bw, https://www.mmegi.bw/index.p hp?sid=1\&aid=72\&dir=2008/March/Thursd ay20/

Smith, A. D. (2014). Africa's Che Guevara': Thomas Sankara's legacy. Accessed on October 15, 2020 from BBC, https://www.b bc.com/news/world-africa-27219307 